\title{
Do differences in future sulfate emission pathways matter for near-term climate? A case study for the Asian monsoon
}

\author{
Rachel E. Bartlett ${ }^{1}$ (D) Massimo A. Bollasina $^{1} \cdot$ Ben B. B. Booth $^{2} \cdot$ Nick J. Dunstone $^{2}$ \\ Franco Marenco $^{2} \cdot$ Gabriele Messori $^{3} \cdot$ Dan J. Bernie $^{2}$
}

Received: 10 August 2016 / Accepted: 4 May 2017 / Published online: 17 May 2017

(c) The Author(s) 2017. This article is an open access publication

\begin{abstract}
Anthropogenic aerosols could dominate over greenhouse gases in driving near-term hydroclimate change, especially in regions with high present-day aerosol loading such as Asia. Uncertainties in near-future aerosol emissions represent a potentially large, yet unexplored, source of ambiguity in climate projections for the coming decades. We investigated the near-term sensitivity of the Asian summer monsoon to aerosols by means of transient modelling experiments using HadGEM2-ES under two existing climate change mitigation scenarios selected to have similar greenhouse gas forcing, but to span a wide range of plausible global sulfur dioxide emissions. Increased sulfate aerosols, predominantly from East Asian sources, lead to large regional dimming through aerosolradiation and aerosol-cloud interactions. This results in surface cooling and anomalous anticyclonic flow over land, while abating the western Pacific subtropical high. The East Asian monsoon circulation weakens and precipitation stagnates over Indochina, resembling the observed southern-flood-northern-drought pattern over China. Large-scale circulation adjustments drive suppression of the South Asian monsoon and a westward extension of the Maritime
\end{abstract}

Electronic supplementary material The online version of this article (doi:10.1007/s00382-017-3726-6) contains supplementary material, which is available to authorized users.

Rachel E. Bartlett

r.e.bartlett@ed.ac.uk

1 School of Geosciences, Grant Institute, University of Edinburgh, Edinburgh EH9 3FE, UK

2 Met Office Hadley Centre, FitzRoy Road, Exeter EX1 3PB, UK

3 Department of Meteorology, Stockholm University, 10691 Stockholm, Sweden
Continent convective region. Remote impacts across the Northern Hemisphere are also generated, including a northwestward shift of West African monsoon rainfall induced by the westward displacement of the Indian Ocean Walker cell, and temperature anomalies in northern midlatitudes linked to propagation of Rossby waves from East Asia. These results indicate that aerosol emissions are a key source of uncertainty in near-term projection of regional and global climate; a careful examination of the uncertainties associated with aerosol pathways in future climate assessments must be highly prioritised.

Keywords Anthropogenic aerosols - Asian monsoon Atmospheric circulation · Precipitation - Climate model · Future scenarios

\section{Introduction}

Anthropogenic climate change is one of the biggest challenges our society faces. Currently much of the research focuses on greenhouse gas (GHG)-induced changes and their impacts, as these are expected to dominate climate variation in long-term future projections (e.g. Westervelt et al. 2015). However, anthropogenic aerosols currently exert a significant forcing on the Earth's radiative balance (Boucher et al. 2013; Shindell et al. 2013). Additionally, although their emissions are expected to decrease rapidly throughout the twenty-first century, aerosols will continue to represent a large source of uncertainty for our estimates of near-future climate change, especially at regional scale (Gillett and Salzen 2013; Rotstayn et al. 2014).

Aerosols can perturb the climate system through radiative and cloud microphysical effects. By scattering and absorbing solar and, to a lesser extent, infrared radiation 
aerosols modify the surface and atmospheric temperature distributions (the so-called direct effect; Charlson et al. 1992). Where absorption occurs, static stability and the surface energy budget are altered and this may, in turn, lead to the evaporation of clouds (cloud burn-off) by atmospheric heating (the semi-direct effect; Hansen et al. 1997), which subsequently reduces radiation scattering by clouds. Furthermore, aerosols acting as cloud condensation nuclei $(\mathrm{CCN})$ interact with cloud microphysical processes and thus affect cloud properties and precipitation formation (the indirect effects; Twomey 1977; Albrecht 1989). The magnitudes of direct, semi-direct and indirect effects vary between aerosol species (e.g. black carbon is strongly absorbing, whereas sulfate aerosols scatter solar radiation and are efficient $\mathrm{CCN}$ ). Additionally, aerosol effects can interact with each other in non-linear ways (Ming and Ramaswamy 2009; Lee et al. 2013) as well as with other regional and, via atmospheric circulation adjustments, remote processes to produce complex impacts on clouds and precipitation.

At the global scale, aerosols are estimated to exert a net negative effective radiative forcing of $-0.9 \mathrm{~W} \mathrm{~m}^{-2}$ on present-day climate (Myhre et al. 2013), offsetting part of the GHG-induced warming. However, aerosols have a short lifetime in the atmosphere and spatially varying sources, resulting in spatially and temporally heterogeneous distributions. The global mean impact of aerosols is therefore not representative of regional circulation and hydroclimate responses, which can be strong (e.g. Ramanathan et al. 2001) even when the magnitude of global forcing remains small.

In assessing future climate response to changes in forcing, Working Group One (WG1) of the Intergovernmental Panel on Climate Change (IPCC) Fifth Assessment Report (AR5) chose to focus on climate model simulations of four Representative Concentration Pathways (RCPs; van Vuuren et al. 2011). The RCPs are based on bottom-up emissions scenarios from the integrated assessment modelling (IAM) literature. These were run through a common reduced-complexity climate model to produce concentration pathways of long-lived GHGs for climate models to use alongside emissions of other short-lived species. Chosen to span the range of 2100 radiative forcing from plausible scenarios in the literature, the RCPs infer a wide range of levels of effort in dealing with GHG-induced climate change, from aggressive mitigation (RCP2.6) to almost business-as-usual (RCP8.5).

While extremely useful in assessing differences in climate model response to a common set of GHG forcing pathways, the RCPs are a very limited set of scenarios with which to represent and examine all future possibilities of mitigation and emissions, especially for aerosols and at regional scale. Similar levels of global mean climate change are possible from very different scenarios of future emissions of short-lived species based on different plausible assumptions about diverse factors such as regional policy priorities, air quality considerations, rates of technological development, and overall mitigation costs (Clarke et al. 2014). As such, the uncertainty in future aerosol emissions and the climate's response to them, particularly regionally, is under-sampled by the RCPs (Bellucci et al. 2015).

One of the regions with the largest present-day anthropogenic aerosol loading is Asia, where largely agrarian societies rely heavily on monsoon precipitation for water and food supply. Because of this reliance even small changes in the spatial and temporal characteristics of the monsoon can present a major challenge. In recent decades, rapid industrialisation and growing population in Asia have led to significant increases in regional anthropogenic aerosol emissions.

A number of studies have found aerosols to play a key role in driving the observed long-term changes in both the South and East Asian summer monsoons during the late twentieth century, including the decreasing trend in Indian summer rainfall (Chung and Ramanathan 2006; Lau and Kim 2010; Bollasina et al. 2011; Guo et al. 2015) and the southern-flood-northern-drought (SFND) pattern over East Asia (Xu 2001; Menon et al. 2002; Guo et al. 2013; Song et al. 2014). The majority of such studies have used global aerosol forcing or emissions, while only a few have separately investigated the impact of regional and remote emissions, finding that aerosols from remote sources may also contribute to monsoon changes (Cowan and Cai 2011; Ganguly et al. 2012; Bollasina et al. 2014; Dong et al. 2016). Given the monsoon's geographical extent (Trenberth et al. 2000), it is conceivable that aerosol-induced changes in the Asian monsoon have the potential to perturb large-scale atmospheric circulation and to impact remote regions (Cowan and Cai 2011; Teng et al. 2012; Mahmood and $\mathrm{Li}$ 2014). While the above studies have highlighted the role of aerosols in recent Asian monsoon variability and possibilities for downstream climate impacts further afield, the future impact of aerosols is largely unexplored and typically investigated by means of idealised aerosol pathways (Teng et al. 2012; Grandey et al. 2016).

This study aims to address the existing knowledge gaps outlined above. Specifically, it investigates the near-term response of the Asian summer monsoon system to future sulfate loading in East Asia based on plausible aerosol emission scenarios and a series of ensemble experiments with a state-of-the-art fully-coupled global climate model. Despite substantial uncertainties, sulfate aerosols currently exert a large global negative forcing on climate due to their optical properties and ability to act as efficient $\mathrm{CCN}$ (Boucher et al. 2013), with even greater impact on regional scales (e.g. Wang et al. 2015). We consider simulations 
based on two existing twenty-first century emission scenarios from IAM which are chosen to have carbon dioxide $\left(\mathrm{CO}_{2}\right)$ radiative forcing in the first half of the century similar to RCP2.6, but which differ strongly in their global sulfur dioxide $\left(\mathrm{SO}_{2}\right)$ emissions. Similarity to RCP2.6 is chosen as a basis for selecting scenarios as this is the RCP with the most aggressive mitigation of greenhouse gas emissions and is the most consistent with the United Nations Framework Convention of Climate Change (UNFCCC) aim of limiting warming to well below $2^{\circ} \mathrm{C}$.

In the two scenarios chosen, underlying regional differences in energy policy and pollution controls result in quite different regionally-varying, time-evolving aerosol emissions and burden. During the first decades, the most significant differences in emissions between these scenarios are found over East Asia; therefore, the study is interpreted as an investigation of the impact of regional aerosol perturbation based on plausible future emission pathways. The remainder of the text is organised as follows: model, experimental design, and emission scenarios are presented in Sect. 2. Section 3 analyses the impact of aerosol emissions on monsoon climate and investigates the underlying physical mechanisms, highlighting the important role of atmospheric dynamical adjustments. Larger-scale impacts over remote regions are also identified. Discussion and conclusions follow in Sect. 4.

\section{Model and experiments}

\subsection{Model}

This study makes use of experiments conducted with the fully-coupled Hadley Centre Global Environment Model version 2-Earth System (HadGEM2-ES; Collins et al. 2011; Jones et al. 2011). The resolution of the atmospheric component is $1.25^{\circ} \times 1.875^{\circ}$ with 38 vertical levels extending to around $39 \mathrm{~km}$. The ocean component has a resolution of approximately $1^{\circ}$, increasing to $1 / 3^{\circ}$ at the equator, and 40 vertical levels. The model includes an interactive land and ocean carbon cycle, dynamic vegetation, and interactive tropospheric chemistry.

The aerosol module in HadGEM2-ES is the Coupled Large-scale Aerosol Simulator for Studies In Climate (CLASSIC) scheme, which simulates concentrations of six aerosol species: ammonium sulfate (referred to as sulfate aerosol), black and organic carbon from fossil fuels, biomass burning aerosols, mineral dust and sea salt. While mineral dust and sea salt aerosol emissions are computed interactively, emissions datasets drive schemes for the other species. The aerosol mass is a prognostic variable, while the number concentrations are derived from assumed (fixed) size distributions, i.e. it is a single-moment scheme.
This mass-based scheme interacts with clouds in the model by using the derived aerosol number concentrations to calculate cloud droplet number concentration (CDNC). All aerosol species can exert direct effects, which can lead to semi-direct effects through modification to atmospheric temperatures. The first and second indirect effects, contributing to changes in cloud albedo and precipitation efficiency, are included for all species except for mineral dust and black carbon. Further details of the aerosol scheme can be found in Bellouin et al. (2011), and in Jones et al. (2011) with reference to the specific version of the model used in this study.

Bellouin et al. (2011) documented the validation of the aerosol scheme used here, finding that representation of aerosol optical depth (AOD) generally compares well to ground-based observations, aside from where mineral dust is overestimated. Comparison to observed surface concentrations shows that sulfate and black carbon aerosols are simulated well overall, while organic carbon is often underestimated in winter and spring. The study also points out that the scheme's externally mixed aerosols may contribute to overestimation of the first indirect effect.

HadGEM2-ES performs reasonably well in simulating the main observed characteristics of the East Asian monsoon (Sperber et al. 2013). Its two main biases over Asia in comparison to observational datasets, a weak southerly flow across the South China Sea and reduced monsoon precipitation over central India, are common, to various degrees, among other Coupled Model Intercomparison Project phase 5 (CMIP5) models (Sperber et al. 2013; Dong et al. 2016). This model has also been recently used to investigate the impact of past anthropogenic aerosols on the monsoon (Dong et al. 2016), providing further support to the experimental set-up of this study.

\subsection{Experiments and methods}

We used two experiments, each consisting of a threemember ensemble with simulations initialised in 2005 from HadGEM2-ES historical runs (Jones et al. 2011) and integrated forward in time driven by two emission scenarios. These scenarios are intended to complement RCP2.6 to the extent that they are broadly similar in terms of their global $\mathrm{CO}_{2}$ forcing trajectory (Fig. 1a), but also to sample the uncertainty range of plausible $\mathrm{SO}_{2}$ emissions (and thereby sulfate) for this aggressive mitigation scenario. To select scenarios, we draw on the database of over 1000 scenarios (Krey et al. 2014) collated by Working Group Three (WG3) of the IPCC as part of AR5 on the basis of finding cumulative $\mathrm{CO}_{2}$ emissions and projected warming similar to RCP2.6. As there is a near linear relation between cumulative $\mathrm{CO}_{2}$ emissions and global temperatures (Allen et al. 2009; Matthews 
(a)

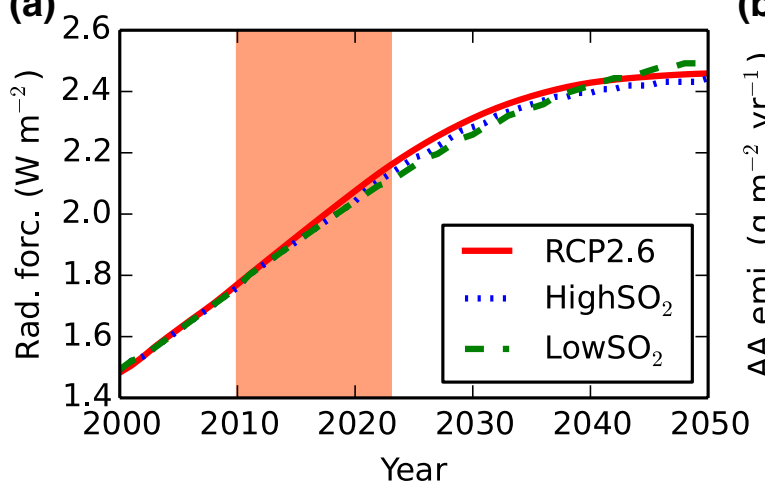

(c)

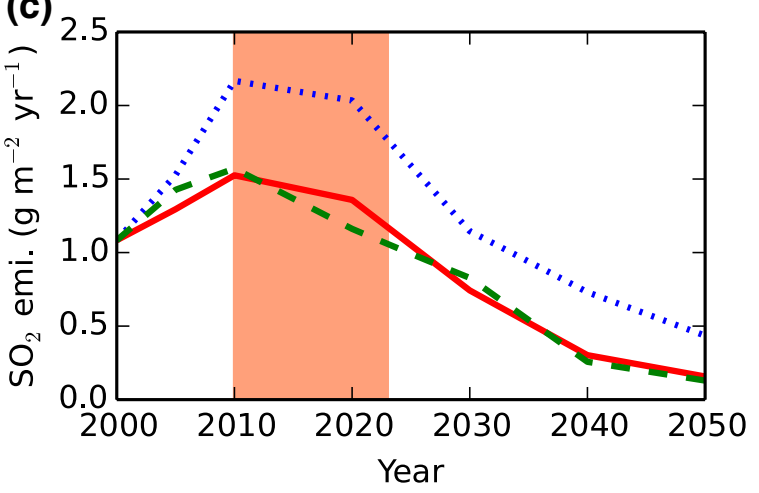

(b)

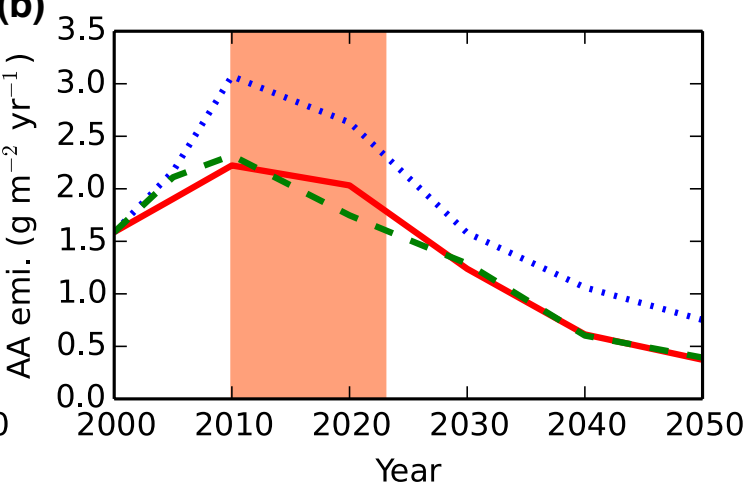

(d)

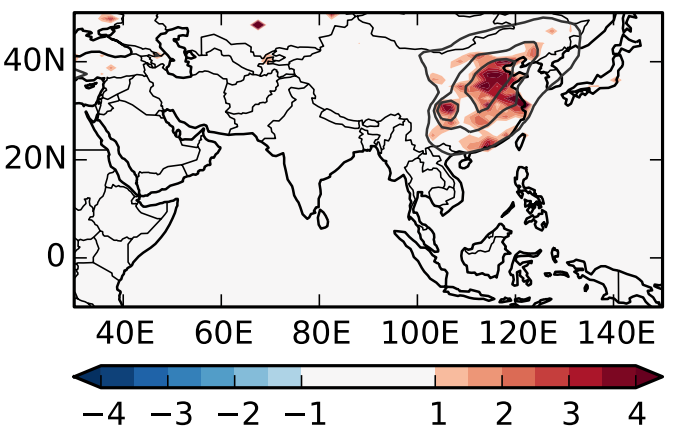

Fig. 1 2000-2050 time series of a global $\mathrm{CO}_{2}$ radiative forcing (W $\mathrm{m}^{-2}$ ); $\mathbf{b}$ emissions of anthropogenic aerosols and their precursors from China $\left(\mathrm{g} \mathrm{m}^{-2}\right.$ year $\left.^{-1}\right)$; and $\mathbf{c} \mathrm{SO}_{2}$ emissions over China $\left(\mathrm{g} \mathrm{m}^{-2}\right.$ year ${ }^{-1}$ ), for RCP2.6 (solid red lines), $\mathrm{HighSO}_{2}$ (dotted blue lines), and $\mathrm{LowSO}_{2}$ (dashed green lines). Here, China covers the domain $100^{\circ}-$ $130^{\circ} \mathrm{E}$ and $20^{\circ}-50^{\circ} \mathrm{N} . \mathrm{CO}_{2}$ radiative forcing is derived by converting

et al. 2009; Meinshausen et al. 2009) applying these criteria individually results in a set of broadly similar pathways, from which we select two that exhibit large differences in their global $\mathrm{SO}_{2}$ emissions profiles and for which regional details of the $\mathrm{SO}_{2}$ emissions are available. RCP2.6 is used as the basis for this selection as it is a widely studied scenario that shows broad consistency with the UNFCCC's Paris agreement, which came into force in November 2016 and demands limiting global climate change to well below $2{ }^{\circ} \mathrm{C}$.

Projected decreases in aerosol and aerosol precursor emissions under all RCP scenarios (Lamarque et al. 2011) contribute, in addition to GHG impacts, towards an expected gradual global mean warming through the twenty-first century as the aerosol cooling effect on climate decreases. However, in the near-term (up to 2035), the strongly mitigated RCP 2.6 has the most rapid decrease in global $\mathrm{SO}_{2}$ emissions. This is one of the factors responsible for RCP2.6 showing the largest near-term global mean warming compared to other RCPs, both in this model (Chalmers et al. 2012) and in the CMIP5 multi-model mean (Kirtman et al. 2013). global mass mixing ratios of $\mathrm{CO}_{2}$ used for the modelling experiments using the same method as Myhre et al. (2013). d The spatial pattern of the difference in annual $\mathrm{SO}_{2}$ emissions $\left(\mathrm{g} \mathrm{m}^{-2}\right.$ year ${ }^{-1} ;$ shades $)$ and June-August (JJA) sulfate column burden $\left(\mathrm{mg} \mathrm{m}^{-2}\right.$; contours at 10 , 20 and $30 \mathrm{mg} \mathrm{m}^{-2}$ ) between $\mathrm{HighSO}_{2}$ and $\mathrm{LowSO}_{2}$ averaged over 2010-2023

The two scenarios selected were created by the Integrated Model to Assess the Global Environment (IMAGE) and the Model for Energy Supply Strategy Alternatives and their General Environmental Impact (MESSAGE) and are hereafter referred to as $\mathrm{HighSO}_{2}$ and $\mathrm{LowSO}_{2}$, respectively. Both are taken from Work Package 2 of the Assessment of Climate Change Mitigation Pathways and Evaluation of the Robustness of Mitigation Cost Estimates (AMPERE) project which looked at costs and feasibility of mitigation scenarios with differing technological assumptions (Riahi et al. 2015). While the specific technological assumptions underlying each scenario are not central to the current study, for completeness the two scenarios selected were IMAGE AMPERE2 450 NucOff-OPT and MESSAGE AMPERE2 450 EERE-OPT.

Although in principle the $\mathrm{HighSO}_{2}$ and $\mathrm{LowSO}_{2}$ scenarios have different anthropogenic aerosol emissions worldwide, the largest widespread differences by emitted mass are found over China (Fig. 1b). This difference is mostly attributable to $\mathrm{SO}_{2}$ emissions (Fig. 1c) because $\mathrm{SO}_{2}$ contributes the largest mass to emissions in the region giving greater scope for variability in future 
evolution; $\mathrm{SO}_{2}$, black carbon, and organic carbon emissions from China in 2010 amounted to about 3.20, 0.19, and $0.42 \mathrm{~g} \mathrm{~m}^{-2}$ year $^{-1}$, respectively, according to a recent estimate (Lu et al. 2011; units converted). The dominance of differences in sulfate aerosols, compared to those of black and organic carbon, is show by column burdens in Fig. S1 (supplementary figures are available in Online Resources). The radiative effect per unit mass of black carbon is stronger than that of sulfate; however, we find that the mass difference in black carbon (and organic carbon) emissions between scenarios is sufficiently small that the consequent radiative impact would be negligible. Related radiative forcing is estimated to be around $0.06 \mathrm{~W} \mathrm{~m}^{-2}$ for black carbon, compared to $2.8 \mathrm{~W} \mathrm{~m}^{-2}$ for sulfate over China, based on mean column burden differences of 0.03 and $14 \mathrm{mg} \mathrm{m}^{-2}$ (Fig. S1d), respectively, and estimates of radiative forcing per unit mass summarised by Haywood and Boucher (2000).

These results are indicative of a large uncertainty associated with projected changes in energy production methods and other socio-economic drivers of change in China, and with the impact of these on near term $\mathrm{SO}_{2}$ emissions. To quantify the extent to which this range can result in regional and large-scale climate anomalies, we focus our analysis on the difference between $\mathrm{HighSO}_{2}$ and $\mathrm{LowSO}_{2}$. Furthermore, given the monsoon emphasis, we will primarily analyse the average June-August (JJA) season, although monthly data will also be used to identify sub-seasonal features.

Common to the two scenarios (and RCP2.6) is the East Asian $\mathrm{SO}_{2}$ emission peak in 2010 and subsequent decline (Fig. 1c). However, the rates at which East Asian emissions increase before 2010 and decrease afterwards are different in $\mathrm{HighSO}_{2}$ and $\mathrm{LowSO}_{2}$, resulting in the largest difference in emissions between scenarios occurring in 2020, with the scenarios converging to give a much smaller difference by 2030 . The yearly values of differences in emissions between $\mathrm{HighSO}_{2}$ and $\mathrm{LowSO}_{2}$ (refer to Fig. 1c) return to within $20 \%$ of the 2010 values in 2023 and successively decrease further. Therefore, focusing on the 2010-2023 period (highlighted in Fig. 1) allows the potential impact of the increased $\mathrm{SO}_{2}$ emissions in the HighSO $\mathrm{H}_{2}$ scenario, compared to those in $\mathrm{LowSO}_{2}$, to be maximised. Although the experiments are conducted with a fully coupled model, the analysis time period is relatively short in comparison to the time scale (a decade or more) required for large-scale oceanic responses to arise due to the ocean's thermal inertia, especially considering that these are transient experiments with continuously evolving forcings. This implies that, while air-sea interactions are accounted for, atmospheric circulation anomalies induced directly by aerosols will likely play a dominant role in driving the changes discussed below.
The spatial pattern of the 2010-2023 mean difference in $\mathrm{SO}_{2}$ emissions between scenarios is displayed, along with column burden, in Fig. 1d, with the large and widespread anomalous sulfate peak over China standing out, even at global scale (Fig. S1a). Spatial and temporal variations of anomalous column burden (Fig. S1) and AOD (not shown due to similarity to column burden) mirror those in emissions, although the transport, processing and deposition of aerosols lead to some differences relative to emissions and contribute to interannual variability. Long-range transPacific transport of aerosols appears to be negligible, but there is evidence of aerosols being progressively advected outside the source region northeastward over the Korean Peninsula and the Sea of Japan (Fig. S1a).

Throughout the analysis, the significance of ensemble mean differences is assessed by means of the two-sample Kolmogorov-Smirnov test, which estimates the likelihood that data are drawn from the same underlying distribution. Additionally, the HadGEM2-ES pre-industrial control experiment (Jones et al. 2011) is used to test the probability that the modelled precipitation patterns might emerge as a result of internal variability alone. The 578-year run has the first 200 years removed and is then split into 364 overlapping 14-year segments. A random sample of 6 segments is taken, the first 3 and last 3 are averaged for a region-to mirror the number of ensemble members in each experiment - and the difference is found. This is repeated 10,000 times to produce that many average differences, and the results are used to create a bootstrapped probability distribution for that region. The regions used are defined in Table S1, which also shows regional average precipitation, temperature, and sea-level pressure differences between scenarios.

\section{Results}

Below we analyse and discuss the difference between the two sets of simulations, i.e. $\mathrm{HighSO}_{2}$ ensemble average minus $\mathrm{LowSO}_{2}$ ensemble average, during the summer period (June-August; JJA) for the years 2010-2023, unless otherwise stated.

\subsection{Near-surface climate and circulation changes over Asia}

We first examine changes to near-surface climate (temperature and precipitation) and atmospheric circulation over Asia in response to increased East Asian $\mathrm{SO}_{2}$ emissions. Larger sulfate loading in $\mathrm{HighSO}_{2}$ compared to that in $\mathrm{LowSO}_{2}$ over eastern China leads to significant regional surface cooling (Fig. 2a), consistent with enhanced radiation scattering, due to the optical properties of sulfate 
(a)
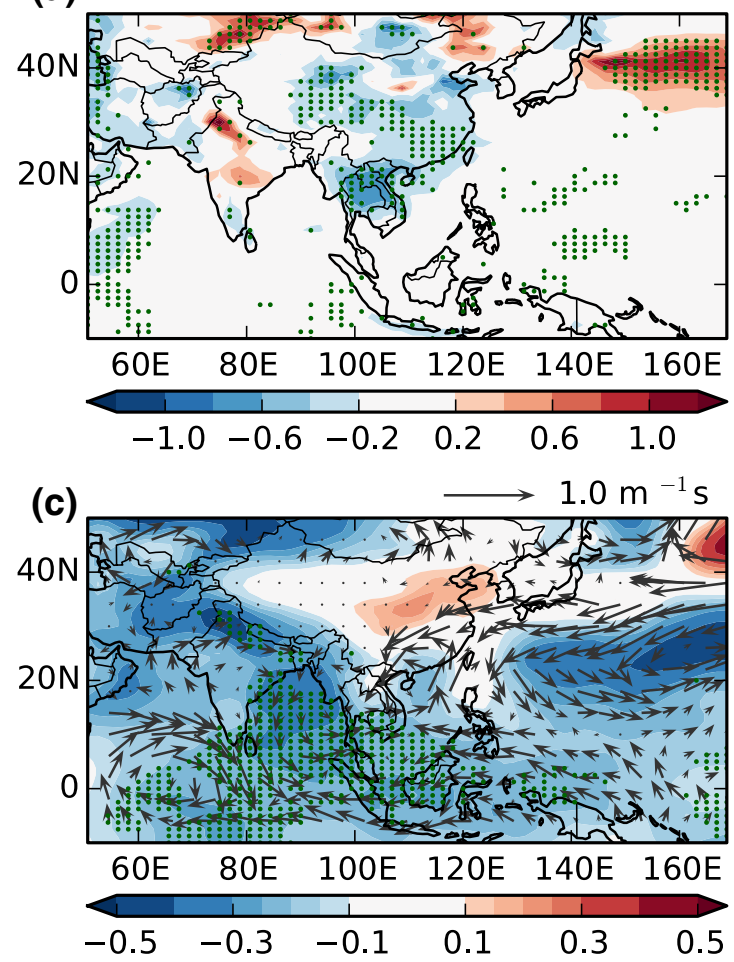

Fig. 2 Spatial patterns of the 2010-2023 mean difference between $\mathrm{HighSO}_{2}$ and LowSO $\mathrm{S}_{2}$ during June-August (JJA) for a surface temperature (K ; for sea-surface temperature differences see figure $\mathrm{S} 3)$; $\mathbf{b}$ precipitation $\left(\mathrm{mm} \mathrm{day}^{-1}\right)$; $\mathbf{c}$ sea level pressure $(\mathrm{hPa}$; shades $)$ and 850 $\mathrm{hPa}$ winds $\left(\mathrm{m} \mathrm{s}^{-1}\right.$; arrows $)$; and $\mathbf{d}$ moisture flux $\left(\mathrm{kg} \mathrm{m}^{-1} \mathrm{~s}^{-1}\right.$; arrows $)$

aerosols, and an expected subsequent surface dimming. Notably, aerosol-induced anomalies extend, and are even more substantial, over areas surrounding the aerosol source region. Surface temperatures in the $\mathrm{HighSO}_{2}$ scenario are significantly cooler than those in $\mathrm{LowSO}_{2}$ across Indochina, while warmer conditions dominate over large parts of India. Anomalous cooling is also found over Southwest Asia and most of the oceanic regions [Fig. S2 shows differences in sea-surface temperature (SST) between scenarios], highlighting the efficient spread of the aerosol-induced cooling perturbation by atmospheric circulation. An exception to this is the northwest Pacific and across the dateline, where there is significant anomalous warming.

Precipitation changes between scenarios (Fig. 2b) feature a meridional dipole pattern over eastern China, with a weak drying to the north and large wetting to the south in $\mathrm{HighSO}_{2}$ relative to LowSO $\mathrm{S}_{2}$; this dipole bears resemblance to the SFND pattern observed during the last decades (Gong and Ho 2002). Our experiments support the hypothesis that increased regional aerosols may play an important role in weakening the East Asian monsoon. Significantly higher precipitation appears over Indochina in $\mathrm{HighSO}_{2}$ compared to that in $\mathrm{LowSO}_{2}$, while rainfall (b)
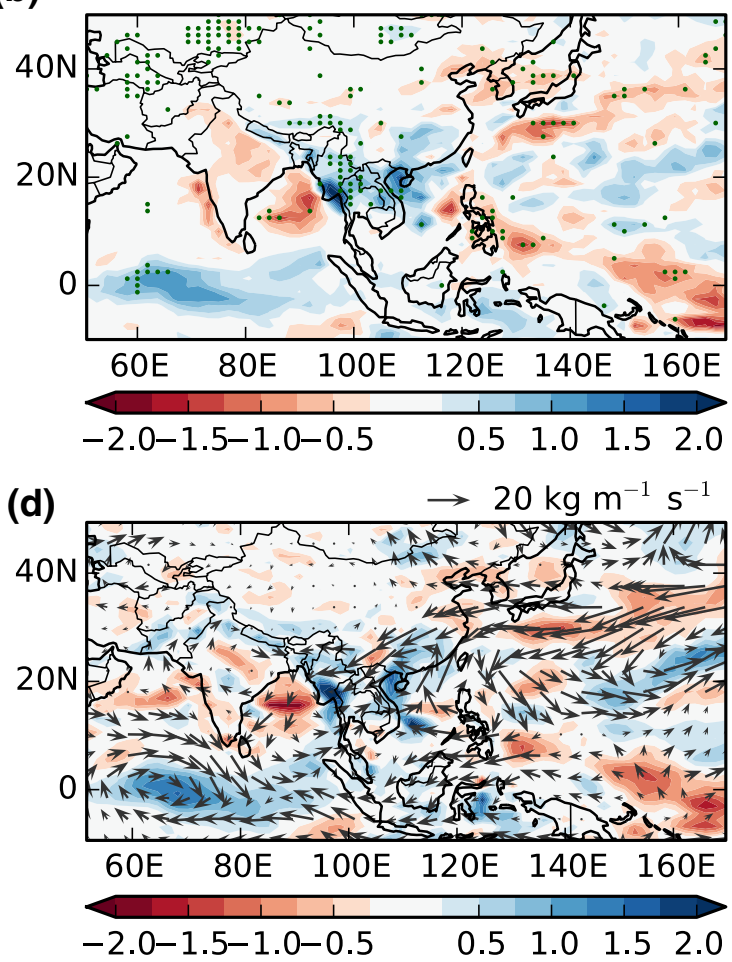

and its convergence (mm day ${ }^{-1}$; shades) vertically integrated from the surface to $300-\mathrm{hPa}$. Stippling in a-c indicates significance at the $90 \%$ level $(\mathrm{p}>0.1)$ using a two-sample Kolmogorov-Smirnov test. Note reversed colour scale in $\mathbf{b}$ and $\mathbf{d}$

is reduced over India. These anomalies, together with the corresponding ones for temperature, are suggestive of a local temperature response to rainfall via cloud and available surface energy changes. Additionally, the drying response over India supports recent findings on the importance of remote aerosol emissions for the Indian monsoon precipitation decrease (Bollasina et al. 2014). Although these changes are not statistically significant, they are consistent with the large-scale pattern of lowerand upper-level circulation anomalies (discussed later), which provides a supporting mechanism.

A notable feature of Fig. $2 \mathrm{~b}$ is the equatorial precipitation change over the western Pacific and eastern Indian Ocean: the suppression of precipitation over the Indonesian region and the Pacific warm pool, together with the enhancement over the central Indian Ocean, suggest an anomalous westward shift of the major convective area in $\mathrm{HighSO}_{2}$ relative to that in LowSO ${ }_{2}$. In other words, there is a broadening and westward-shift of the climatological Indo-Pacific convection region: a characteristic feature of the tropical circulation response to aerosol forcing (Bollasina et al. 2011; Ming and Ramaswamy 2011; Xie et al. 2013), and indicative of changes to the local Walker cell. 
Further confidence in our results is provided by computing probability distributions of precipitation differences between randomly selected 14-year JJA means from the model pre-industrial control experiment for various regions (Fig. S3; method described previously). This bootstrapping method confirms that the widespread positive precipitation anomaly over Indochina and southern China, a key characteristic of the precipitation changes in our results, is more than $99.9 \%$ significant $\left(+0.52 \mathrm{~mm} \mathrm{day}^{-1}\right.$ for the area $94^{\circ}-114^{\circ} \mathrm{E}, 12^{\circ}-28^{\circ} \mathrm{N}$; see Table $\mathrm{S} 1$ for average surface anomalies over a number of regions shown in Fig. S3a) and is therefore well beyond the range of the model's internal variability (Fig. S3b).

To understand how such precipitation anomalies are brought about we next consider near-surface circulation. Moisture transport from the oceans and its convergence over land is the main source of continental precipitation for the monsoon. Therefore, changes in the lower-tropospheric atmospheric circulation are key factors underpinning precipitation changes. Figure $2 \mathrm{c}$ shows the development of an anomalous high pressure over the region of increased sulfate aerosols, consistent with the anomalous surface cooling described previously. Another distinct feature is the weakening of the western Pacific subtropical high (WPSH) in $\mathrm{HighSO}_{2}$ relative to $\mathrm{LowSO}_{2}$. The WPSH is a key element of the East Asian summer monsoon (Chang et al. 2000), associated with a reversal of the zonal temperature gradient between the land and the nearby ocean and a subsequent redistribution of mass. As a result, anomalous northeasterly winds blow over eastern China in $\mathrm{HighSO}_{2}$ compared to those in $\mathrm{LowSO}_{2}$, opposing the climatological southwesterlies and weakening the East Asian monsoon circulation. Also, the moisture transport difference between $\mathrm{HighSO}_{2}$ and $\mathrm{LowSO}_{2}$ (Fig. 2d) is divergent over northern China and convergent to the south where strong easterlies blow across Indochina. As a result, the precipitation front stagnates to the south and does not reach northern China, similarly to Dong et al. (2016).

Lower-tropospheric northeasterly wind anomalies over the Bay of Bengal obstruct the climatological southwesterly moisture-laden wind from the Arabian Sea and deflect it southward, resulting in anomalous moisture flux divergence and drier conditions over India in $\mathrm{HighSO}_{2}$ compared to those in $\mathrm{LowSO}_{2}$. This anomalous flow contributes to the widespread convergence area over the central equatorial Indian Ocean, together with the extensive and moisture-rich anomalous equatorial easterlies blowing across the Maritime Continent and linked to the westward rainfall shift discussed above.

Given that the Asian monsoon is predominantly characterised by the meridional migration of precipitation, timelatitude sections provide important insights on the subseasonal evolution of the rainfall anomalies over key areas
(Fig. 3). These show that the precipitation enhancement over Indochina in $\mathrm{HighSO}_{2}$ relative to $\mathrm{LowSO}_{2}$ (Fig. 3a) is persistent throughout the summer (JJA). Conversely, the precipitation suppression over India (Fig. 3b) and increase over southern China (Fig. 3c) occurs in July and August only, and is preceded by opposite sign anomalies (i.e. resulting in an earlier South Asian monsoon onset and later East Asian monsoon onset in $\mathrm{HighSO}_{2}$ compared to those in $\mathrm{LowSO}_{2}$ ). Further, a competition between oceanic and land anomalies is clearly noticeable over the Indian sector. Additionally, the drier September over southern China and Indochina is suggestive of an earlier withdrawal of the East Asian monsoon in $\mathrm{HighSO}_{2}$ compared to that in $\mathrm{LowSO}_{2}$, accompanied by the appearance of wet anomalies across the Indian basin in autumn.

Time series of temperature and precipitation differences between scenarios (Fig. S4) reveal more details on the development and evolution of the mean spatial patterns discussed above. Despite aerosols interacting with fast atmospheric processes, precipitation anomalies grow relatively slowly and not necessarily monotonically in the early stages, reaching larger values after the peak in aerosol emissions differences between scenarios, rather than coinciding with the peak. The evolution of the temperature anomaly over northern China shows a large initial cooling in response to increased overlying aerosols, subsequently partially offset by the warming induced by reduced precipitation and associated decrease in evaporative cooling, as well as decreased cloud cover. The development and evolution of sea-level pressure anomalies over China closely track temperature anomaly variations. However, there is a noticeable lag in the weakening of the WPSH and the appearance of the associated anomalous northerly flow, which in turn leads the anomalous drying in northern China.

\subsection{Radiation and cloud changes}

In order to gain a better understanding of how the regional aerosol impact is generated, we now turn to the analysis of radiation and cloud changes. The difference in shortwave radiation between scenarios is depicted in Fig. 4. Increased sulfate loading over China in the $\mathrm{HighSO}_{2}$ scenario compared to that in LowSO $\mathrm{S}_{2}$, especially over the northeastern areas, results in decreased net shortwave radiation at the top of the atmosphere (TOA; Fig. 4a, b) and at the surface (Fig. 4c, d). Surface and TOA anomalies are of comparable magnitude over China (within $1 \mathrm{~W} \mathrm{~m}^{-2}$ of one another) and can be as large as $-10 \mathrm{~W} \mathrm{~m}^{-2}$, indicating the dominant role of scattering by sulfate aerosols. The decrease is about half of that shown by Guo et al. (2013), but this discrepancy can be explained as the aforementioned study considered a 
(a)

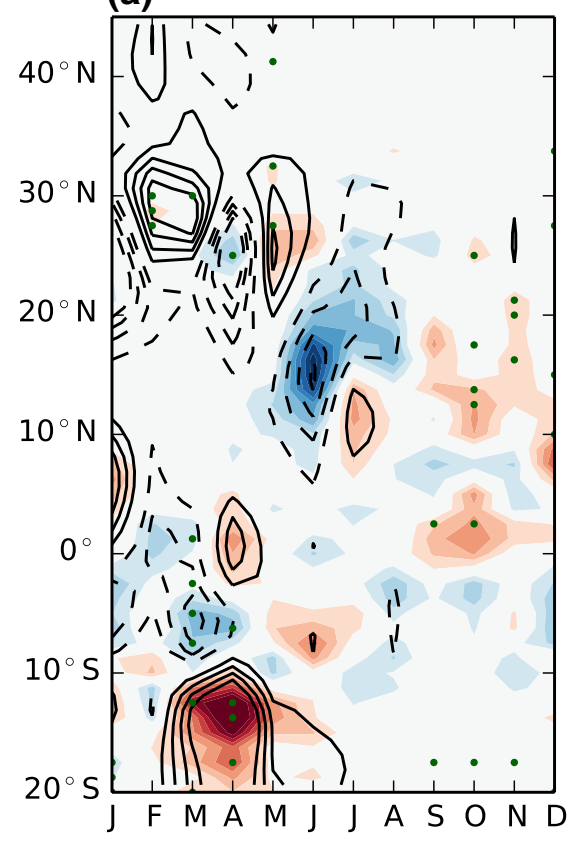

(b)

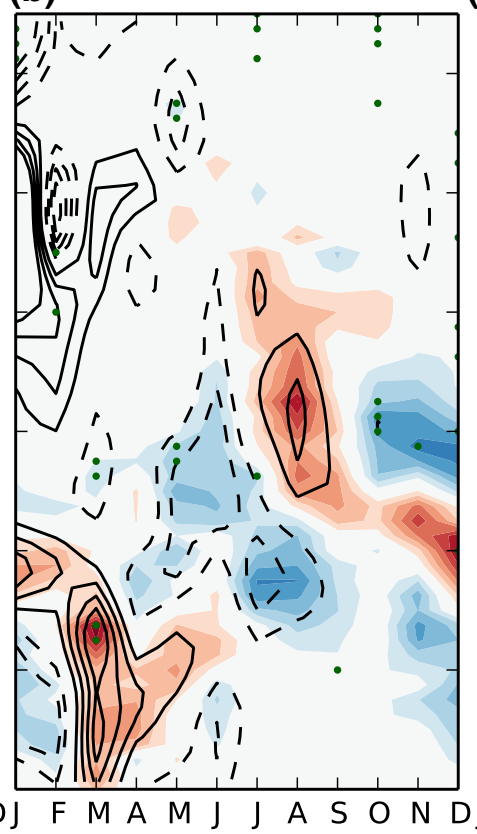

(c)

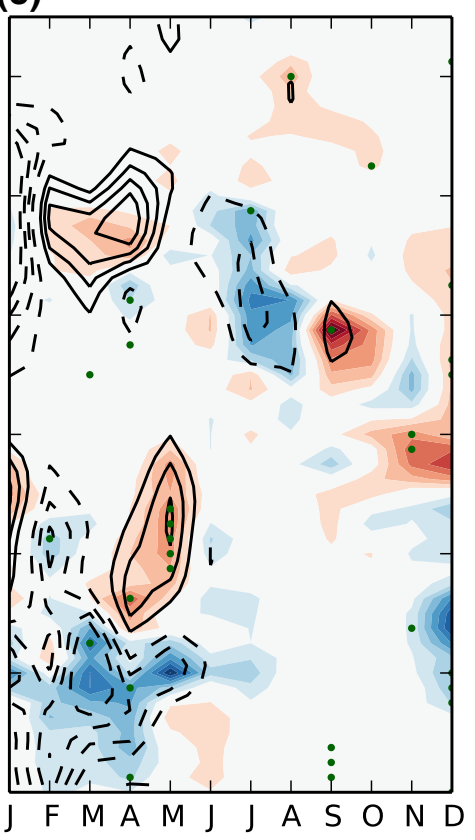

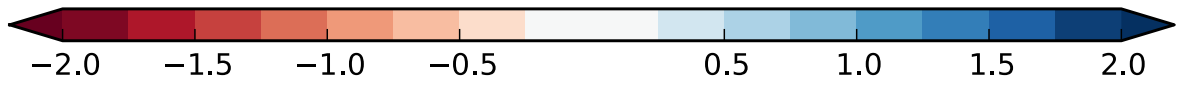

Fig. 3 Annual Hovmöller plots of $\mathrm{HighSO}_{2}$ minus $\mathrm{LowSO}_{2}$ averaged over 2010-2023 for precipitation ( $\mathrm{mm} \mathrm{day}^{-1}$; shades) and omega vertical velocity (hPa day ${ }^{-1}$; contours; smoothed spatially using 9-point smoothing repeated five times) averaged over longitudes a $95^{\circ}-105^{\circ} \mathrm{E}$ (Indochina); b $70^{\circ}-90^{\circ} \mathrm{E}$ (India); and c $105^{\circ}-120^{\circ} \mathrm{E}$ (eastern China).
For vertical velocity, solid (dashed) contours indicate positive (negative) values and downward (upward) motion. Contour intervals are $2.5 \mathrm{hPa} \mathrm{day}^{-1}$ except with no zero contour shown. Stippling indicates significance at the $90 \%$ level ( $p>0.1$ ) using a two-sample Kolmogorov-Smirnov test for precipitation data much larger difference in sulfate loading than ours by comparing present-day aerosols to 1950 .

The difference between the magnitude of all-sky (i.e. including clouds; Fig. 4a, c for TOA and surface, respectively) and clear-sky (i.e. with clouds removed; Fig. 4b, d) shortwave radiation changes represents shortwave cloud forcing, which can be used to infer aerosol-cloud effects. Over the dominant aerosol source region, changes in cloud forcing between scenarios are evident, although not always large. It is possible that the aerosol indirect effect plays a role in this anomalous forcing.

Outside of the aerosol source region, clear-sky (Fig. 4a, c) and all-sky (Fig. 4b, d) shortwave radiation anomalies show very different spatial patterns, indicating changes to cloud forcing between scenarios. The anomalous warming over the northwest Pacific coincides with increased all-sky radiation and negligible changes in clear-sky radiation, indicating decreased radiation scattering by clouds in $\mathrm{HighSO}_{2}$ compared to those in $\mathrm{LowSO}_{2}$. Over Indochina, there is a decrease in all-sky but not clear-sky shortwave radiation, suggesting increased cloud fraction associated with increased precipitation in $\mathrm{HighSO}_{2}$ compared to that in $\mathrm{LowSO}_{2}$.
Decreases in clear-sky shortwave radiation occur over India and across the Arabian Sea in $\mathrm{HighSO}_{2}$ relative to Low $\mathrm{SO}_{2}$, likely linked to changes in mineral dust loading (not shown) as a result of enhanced westerly transport across the Arabian Sea as well as reduced washout over India.

Changes in the net TOA longwave radiation flux (Fig. $\mathrm{S} 5 \mathrm{a}$ and $\mathrm{b}$ ) - in response to increased sulfate in $\mathrm{HighSO}_{2}$ versus $\mathrm{LowSO}_{2}$-are negative over China (i.e. there is less upward longwave radiation), resulting from surface longwave emissions being largely trapped by increased cloud cover in the region, and also due to TOA longwave radiation emitted from cloud tops at colder temperatures than at the ground. Similarly, changes in the net surface longwave radiation flux are positive (i.e. there is more downward longwave radiation; Fig. S5c and d) due to trapping of longwave emissions below the cloud layer, linked to increased cloud cover in $\mathrm{HighSO}_{2}$ compared to that in $\mathrm{LowSO}_{2}$. Note that all-sky changes (Fig. S5a and c) are substantially larger than those for clear-sky (Fig. S5b and d), although clearsky changes do exist in some regions. This is indicative of the limited interaction between sulfate aerosols and longwave radiation. 
(a)

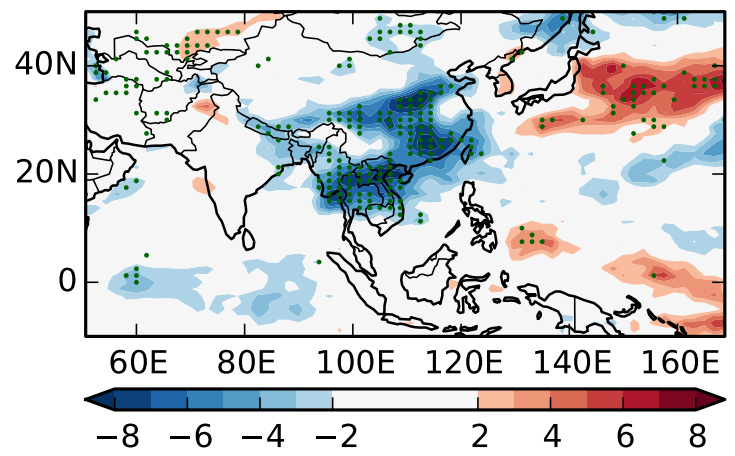

(c)

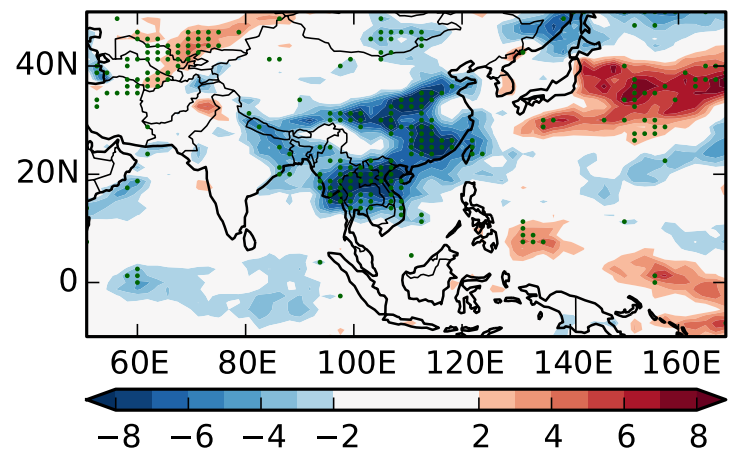

Fig. 4 Spatial patterns of the 2010-2023 mean difference between $\mathrm{HighSO}_{2}$ and $\mathrm{LowSO}_{2}$ during June-August (JJA) for a all-sky net top-of-atmosphere (TOA) shortwave radiation; b clear-sky net TOA shortwave radiation; $\mathbf{c}$ all-sky net surface shortwave radiation; and $\mathbf{d}$

Figure 5 shows differences in cloud properties between $\mathrm{HighSO}_{2}$ and $\mathrm{LowSO}_{2}$, which can be related to radiation changes. Increased low-level cloud fraction (Fig. 5a) and liquid water path (Fig. 5b) are consistent with decreased all-sky shortwave radiation over Indochina, in correspondence with increased precipitation in $\mathrm{HighSO}_{2}$ compared to Low $\mathrm{SO}_{2}$. Meanwhile, decreased low cloud cover and liquid water path over India suggest that reduced cloud cover contributes to the anomalous warming seen in the region. Similarly, over the northwest Pacific, liquid water path is reduced in $\mathrm{HighSO}_{2}$ relative to LowSO ${ }_{2}$, together with decreased all-sky shortwave radiation and increased temperatures. Cloud fraction in Fig. 5a is not reduced over the whole warming region in the northwest Pacific, however, anomalous surface warming is collocated with cloud reduction on lower vertical levels (not shown). While there is some variation in spatial patterns and magnitudes of cloud fraction anomalies between different vertical levels (not shown), the patterns are broadly similar to those shown in Fig. 5a and consistent through low levels of the vertical column, despite some minor differences.

CDNC (Fig. 5c) and cloud droplet effective radius (CDER; Fig. 5d) differences between $\mathrm{HighSO}_{2}$ and Low $\mathrm{SO}_{2}$ are largely opposite over China as might be (b)

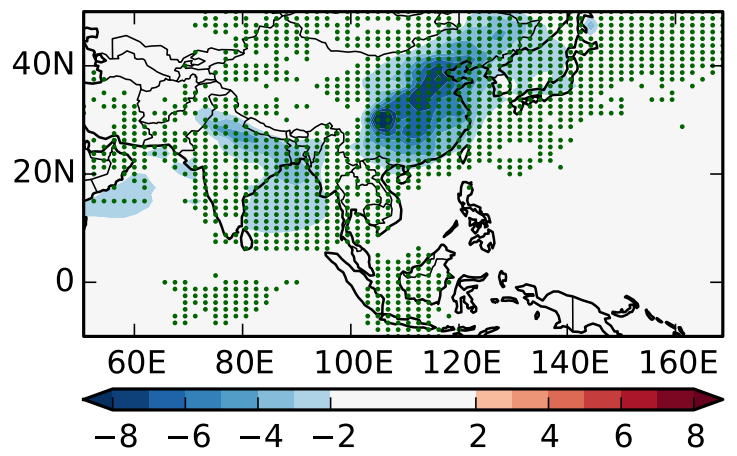

(d)

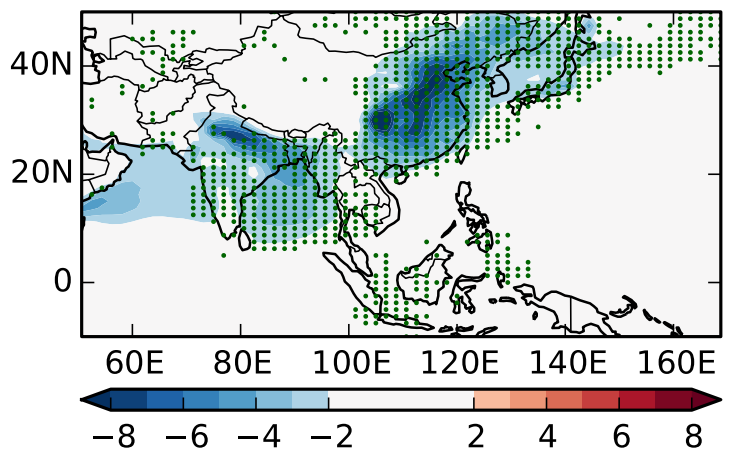

clear-sky net surface shortwave radiation, all with units of $\mathrm{W} \mathrm{m}^{-2}$. Stippling indicates significance at the $90 \%$ level ( $p>0.1)$ using a twosample Kolmogorov-Smirnov test. Note that downward (upward) radiation flux is represented by positive (negative) values

expected for the cloud-albedo aerosol effect: as the number of cloud droplets in a given volume increases in the presence of more CCN (i.e. aerosol particles), the size of the droplets must decrease, provided the amount of liquid water does not undergo substantial changes. However, our results do show changes in liquid water path, possibly due to cloud-lifetime aerosol effects. Quantitatively diagnosing aerosol indirect effects is beyond the scope of this study, but such effects seem likely to play a role based on this qualitative assessment.

\subsection{Changes in the large-scale three-dimensional atmospheric circulation}

An analysis of large-scale atmospheric circulation changes helps to build a consistent three-dimensional dynamical and thermodynamical portrayal of the aerosol-induced changes. The spatial patterns of anomalous upper-level divergent circulation (Fig. 6a) and 500-hPa vertical velocity (Fig. 6b) are in close agreement with that of precipitation anomalies, with areas of anomalous upper-tropospheric divergence and strong upward motion corresponding to precipitation increases in $\mathrm{HighSO}_{2}$ relative to $\mathrm{LowSO}_{2}$. This is not surprising, given the approximate balance between diabatic 
(a)

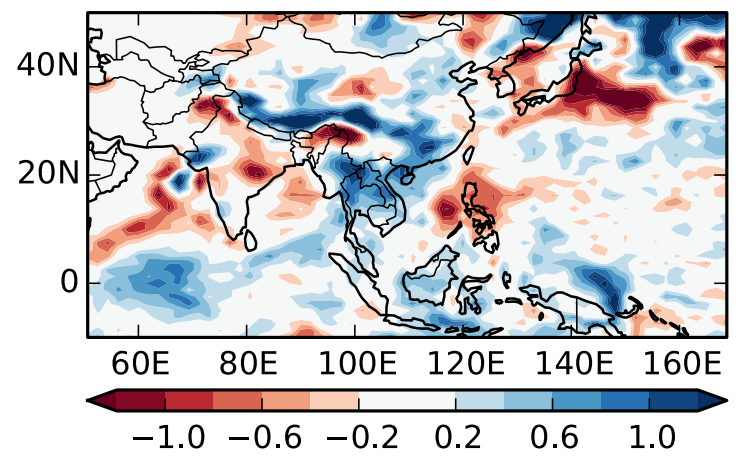

(c)

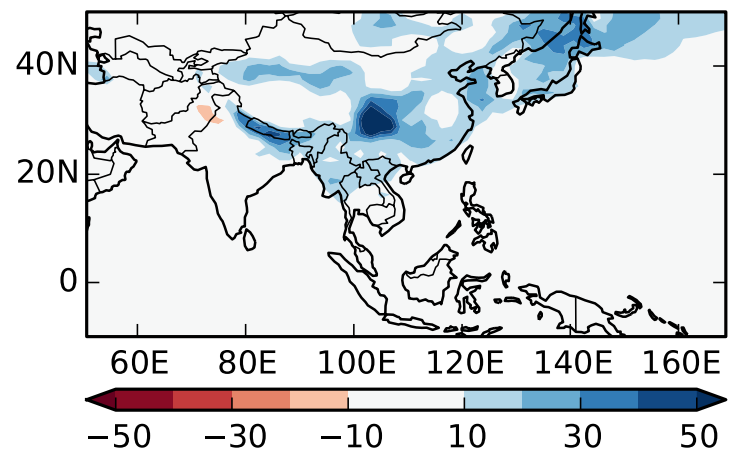

Fig. 5 Spatial patterns of the 2010-2023 mean difference between $\mathrm{HighSO}_{2}$ and $\mathrm{LowSO}_{2}$ during June-August (JJA) for a low cloud fraction (\%) from the model hybrid height level at approximately

heating (e.g. latent heat release from condensation) and mid-tropospheric vertical motion in the tropics and subtropics, the latter creating a closed circulation cell by lower-level convergence and upper-level divergence.

The strongest difference in upper-tropospheric divergent flow between $\mathrm{HighSO}_{2}$ and $\mathrm{LowSO}_{2}$ (Fig. 6a) originates over Indochina and the eastern equatorial Indian Ocean. Flow diverging anomalously over Indochina is directed predominantly to the north and east, converging and inducing downward motion over northern China, which strengthens the surface high pressure anomaly, thus providing a positive feedback with the local precipitation reduction. This makes up the closed meridional circulation cell shown in Fig. $6 \mathrm{c}$ between $20^{\circ} \mathrm{N}$ and $40^{\circ} \mathrm{N}$. Further, anomalous convergence, linked to outflow regions previously mentioned, occurs over India, creating a zonal closed cell from $60^{\circ} \mathrm{E}$ to $110^{\circ} \mathrm{E}$ (Fig. 6d), with the descending branch acting to suppress convection. Also notable is the large-scale anomalous convergence and subsidence over the western equatorial Pacific Ocean, related to the divergence over Indochina and the equatorial Indian Ocean. These patterns demonstrate how the increased sulfate influences atmospheric circulation, both locally and remotely. This strong dynamical link is not exclusive to the summer, but is evident throughout (b)

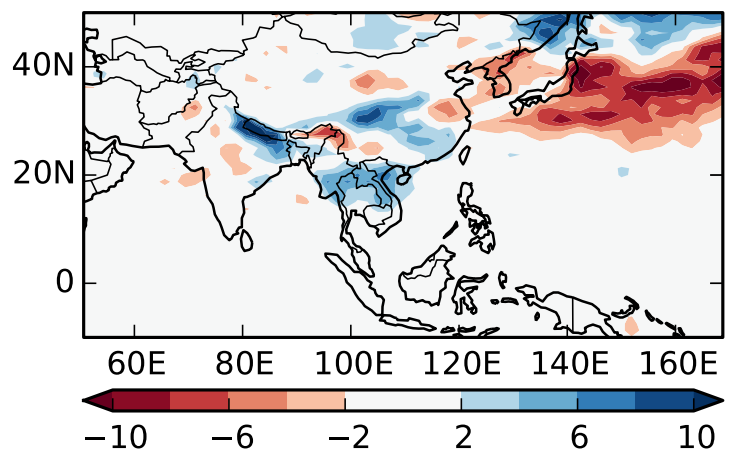

(d)

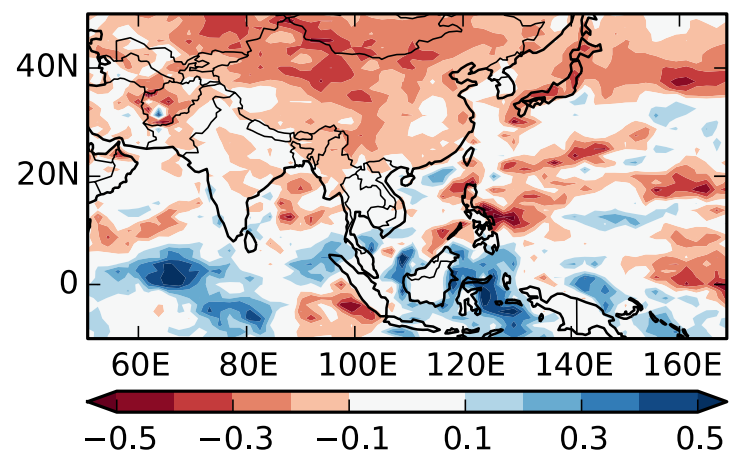

$980 \mathrm{~m}$; b liquid water path $\left(\mathrm{g} \mathrm{m}^{-2}\right)$; c column cloud droplet number concentration $\left(\mathrm{m}^{-2}\right)$; and $\mathbf{d}$ cloud droplet effective radius $(\mu \mathrm{m})$

the whole year (see contour lines in Fig. 3 showing differences between $\mathrm{HighSO}_{2}$ and $\mathrm{LowSO}_{2} 500-\mathrm{hPa}$ vertical velocity), with the monthly evolution of $500-\mathrm{hPa}$ vertical velocity differences between the scenarios generally following that of precipitation.

Figure 7 suggests that increased East Asian sulfate aerosols may induce large anomalies in the upper troposphere leading to teleconnections across the Northern Hemisphere, with the potential to affect climate over remote regions. The velocity potential, associated with the irrotational component of the flow, portrays the broad-scale features of upperlevel divergence and convergence and thus convectivelydriven motions in the tropics. From the pattern of velocity potential differences between $\mathrm{HighSO}_{2}$ and $\mathrm{LowSO}_{2}$ shown in Fig. $7 \mathrm{a}$, it is quite clear that the anomalous tropical circulation associated with increased aerosols consists of a number of divergent circulations in the zonal as well as in the meridional planes. Widespread divergent outflow centres are present over the equatorial Indian Ocean, Indochina, and the western equatorial Atlantic, coinciding with the areas of more intense precipitation. Convergence centres are found over the equatorial western Pacific, the Gulf of Guinea and China. Changes to widespread divergence and convergence outside of Asia, the Indian Ocean and 
(a)

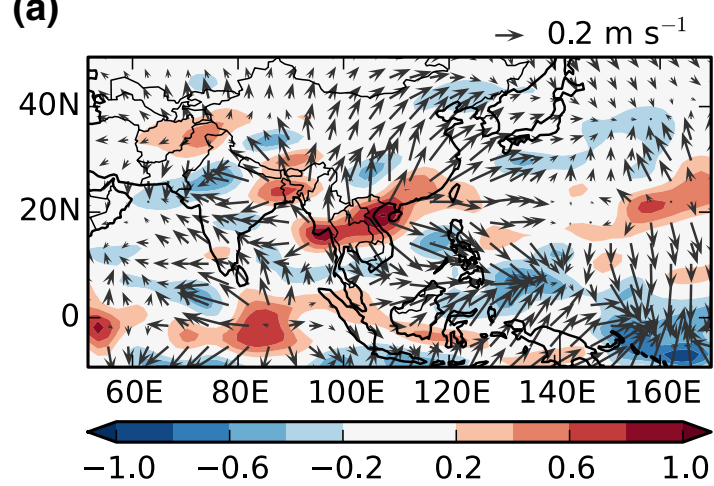

(c)

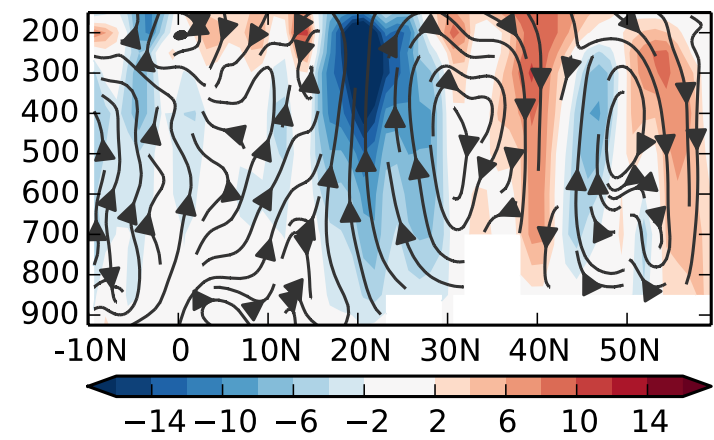

Fig. 6 Spatial patterns of the 2010-2023 mean difference between $\mathrm{HighSO}_{2}$ and $\mathrm{LowSO}_{2}$ during June-August (JJA) for a $150-\mathrm{hPa}$ divergent wind $\left(\mathrm{m} \mathrm{s}^{-1}\right.$; arrows) and its (9-point spatially smoothed) divergence $\left(10^{6} \mathrm{~s}^{-1}\right.$; shades $)$; b 500-hPa omega vertical velocity (hPa day $\left.^{-1}\right) ; \mathbf{c}$ omega vertical velocity (hPa day ${ }^{-1}$; shades) with meridional divergent circulation (streamlines) averaged over $105^{\circ}-120^{\circ} \mathrm{E}$; and $\mathbf{d}$

western Pacific Ocean are evidence of circumglobal shifts in the zonal circulation, including the Pacific Walker cell. Such significant hemispheric-scale changes to upper-level dynamics can propagate downward to generate important impacts upon surface climate.

The HighSO $\mathrm{S}_{2}$ minus $\mathrm{LowSO}_{2}$ difference in the $250-\mathrm{hPa}$ eddy streamfunction (Fig. 7b; contours) displays a wavelike pattern in the midlatitudes with a wavenumber four. In the vertical, the waves have an equivalent barotropic structure with the largest amplitude between 250 and $150 \mathrm{hPa}$ (not shown). The northeastward-directed anomaly pattern across East Asia and the North Pacific suggests the wave train to be ultimately generated by the large positive diabatic heating anomaly (up to $0.5 \mathrm{~K} \mathrm{day}^{-1}$ at $500 \mathrm{hPa}$ compared to the climatological $2.5 \mathrm{~K} \mathrm{day}^{-1}$ ) associated with increased precipitation over Southeast Asia. Note also the expected anticyclonic (cyclonic) anomaly to the northwest (northeast) of the heating anomaly. The northward displacement of the wave train with respect to the heating anomaly is understandable as the Rossby wave source (not shown) is largest at about $40^{\circ} \mathrm{N}$, where the strong northward divergent wind from increased Southeast Asian precipitation (b)

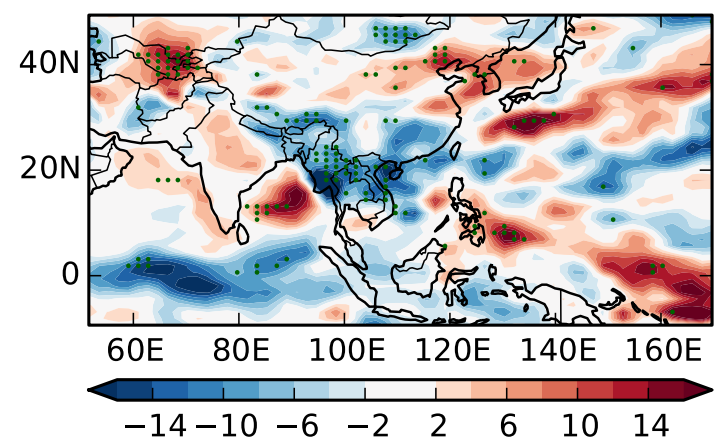

(d)

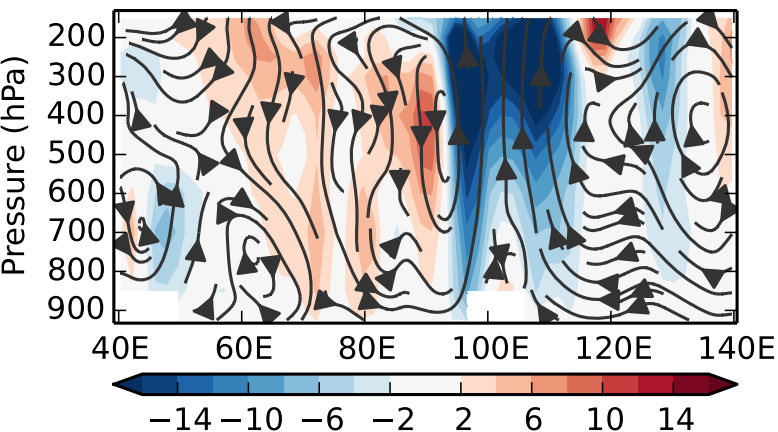

omega vertical velocity $\left(\mathrm{hPa}\right.$ day $^{-1}$; shades) with zonal divergent circulation (streamlines) averaged over $12^{\circ}-22^{\circ} \mathrm{N}$. Orography is masked and appears white in the vertical cross-sections. Stippling in $\mathbf{c}$ indicates significance at the $90 \%$ level $(\mathrm{p}>0.1)$ using a two-sample Kolmogorov-Smirnov test

interacts with the Asian upper-level jet maximum. This forcing excites waves that propagate from Indochina northeastward over the North Pacific, which then turns into an equatorward branch over the northwestern US.

A pattern with similar broad-scale features was described by Sardeshmukh and Hoskins (1988; see their Fig. 9a) as a response to an imposed heating anomaly over Southeast Asia, and by Jin and Hoskins (1995) as a response to tropical heating along the equatorial western Pacific. Some discrepancies between our study and the above are expected because of their highly idealised steadystate setting where the imposed heating is the only perturbation. Further, our experiments include various forcings and feedbacks across the globe (e.g. from local precipitation changes), with locally and remotely forced responses able to interact and compete with one another, for example, over Europe.

Differences in upper level meridional wind between $\mathrm{HighSO}_{2}$ and $\mathrm{LowSO}_{2}$ (Fig. 7b; shades) provides further evidence of a Rossby wave response, showing an alternating pattern of positive and negative anomalies emanating from Southeast Asia, which corresponds well to the 
Fig. 7 Spatial patterns of the 2010-2023 mean difference between $\mathrm{HighSO}_{2}$ and $\mathrm{LowSO}_{2}$ during June-August (JJA) for a 250 -hPa velocity potential $\left(10^{5}\right.$ $\mathrm{m}^{2} \mathrm{~s}^{-1}$; shades) with $\mathrm{LowSO}_{2}$ average values for the same time period (contours every $30 \times 10^{5} \mathrm{~m}^{2} \mathrm{~s}^{-1}$ excluding the zero contour); $\mathbf{b}$ meridional wind velocity ( $\mathrm{m} \mathrm{s}^{-1}$; shades) and streamfunction (contours every $4 \times 10^{5} \mathrm{~m}^{2} \mathrm{~s}^{-1}$, starting at $\pm 2 \times 10^{5} \mathrm{~m}^{2} \mathrm{~s}^{-1}$; smoothed spatially using 9-point smoothing); and $\mathbf{c}$ wave activity flux $\left(\mathrm{m}^{2}\right.$ $\mathrm{s}^{-2}$; arrows) and its divergence $\left(\mathrm{m} \mathrm{s}^{-2} ;\right.$ shades). Solid (dashed) contours indicate positive (negative) values. Stippling in $\mathbf{a}$ and $\mathbf{b}$ indicates significance at the $90 \%$ level $(\mathrm{p}>0.1)$ using a two-sample Kolmogorov-Smirnov test for velocity potential and meridional wind velocity, respectively (a)

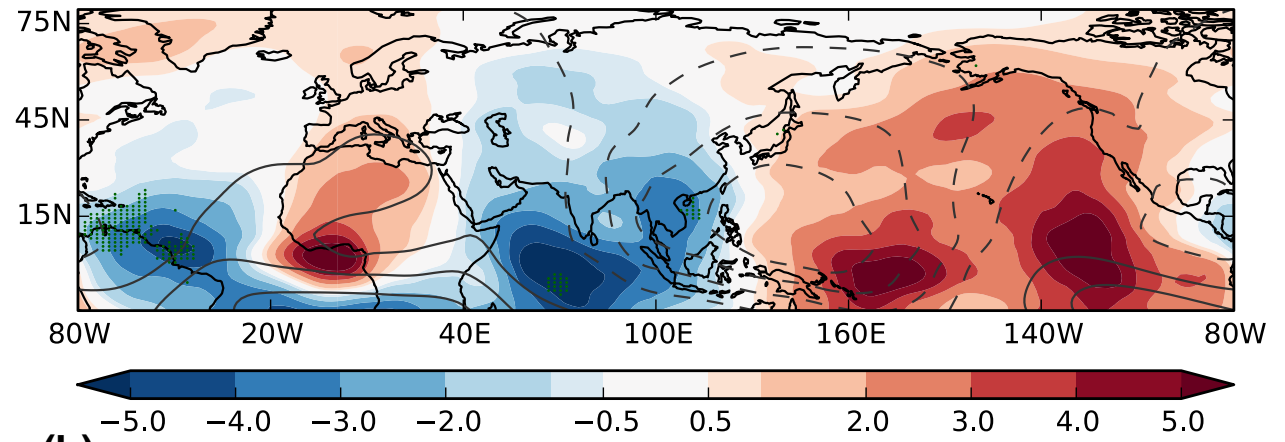

(b)

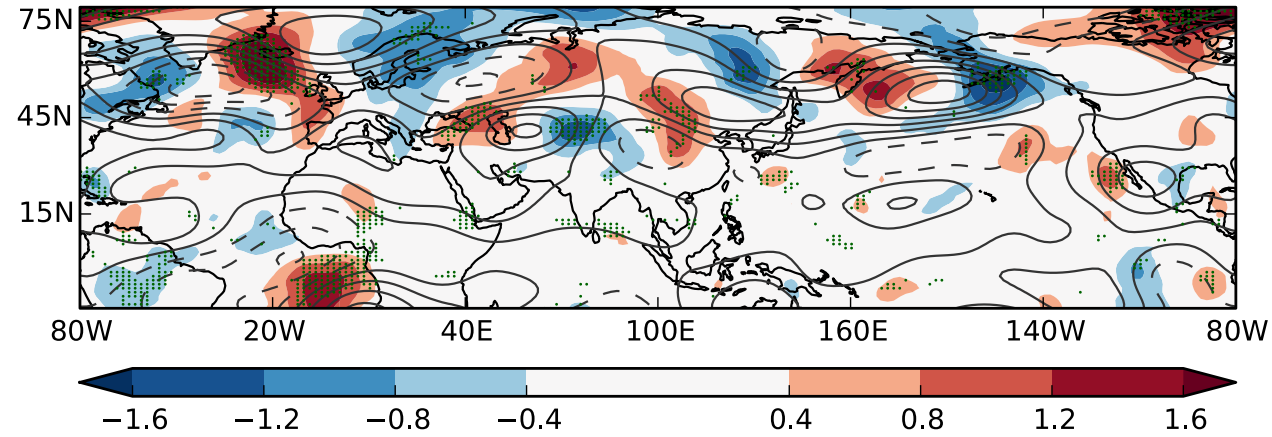

(c)

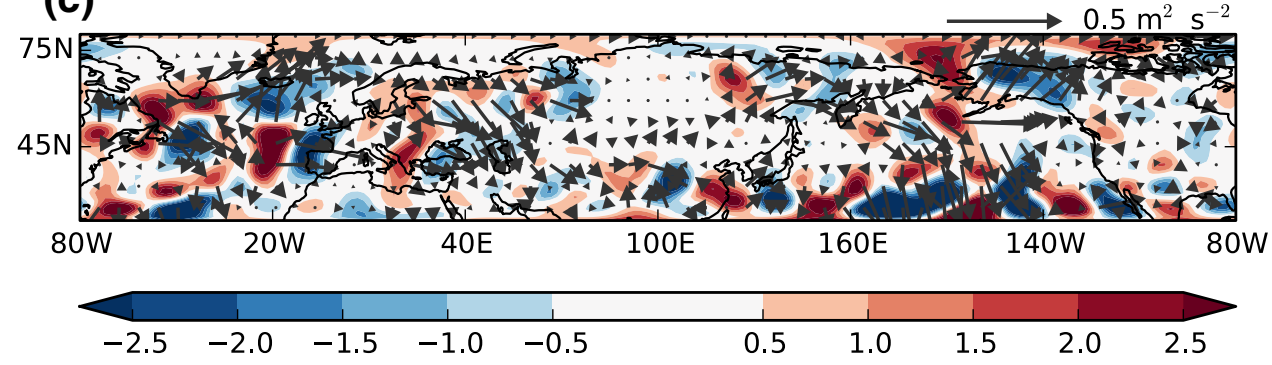

streamfunction anomalies described above. By invoking the large-scale vorticity (Sverdrup) balance, the associated pattern of vertical motion can be inferred; this would, for example, result in anomalous subsidence (ascent) to the east (west) of the trough over China.

The wave activity flux (Fig. 7c; arrows) is a diagnostic tool for the propagation of wave activity. We calculate it following Takaya and Nakamura (2001), ignoring the vertical terms and assuming that the phase propagation term is small enough to be neglected. Divergence (convergence) of the wave activity flux (Fig. 7c; shades) then indicates a source (sink) of stationary wave activity. The vectors are parallel to the wave's group velocity, thus indicating the direction of propagation of the stationary Rossby waves. Clearly, there is propagation of wave activity along $30^{\circ}-60^{\circ} \mathrm{N}$ corresponding to the zonal wave pattern in the 250-hPa streamfunction anomaly.

The wave-flux has a widespread divergent component over southern China, suggesting that this area is a (but not the only) source region for wave activity. The wave train propagates northeastward and, after crossing the US, is amplified at the exit of the Atlantic jet and successively moves southeastward across Europe and Central Asia. This wave train resembles the circumglobal teleconnection pattern described by Ding and Wang (2005), in which Asian monsoon diabatic heating acts as a primary forcing, possibly reinforced by interactions with anomalies over western Europe. Lin (2009) found a similar circumglobal teleconnection pattern in the extratropics induced by monsoonal heating over South Asia, providing further support for farreaching anomalies associated with monsoon changes.

\subsection{Signature on global surface climate}

It is reasonable to expect that the above hemispheric circulation changes may influence near-surface climate over remote areas. As previously pointed out in Sect. 2.2, differences in black carbon and organic carbon column burden between scenarios are very small (Fig. S1) over most of the globe and are therefore unlikely to contribute to regional 
climate anomalies of the same magnitude as the sulfate response. This implicates atmospheric circulation adjustments as the primary factor in the remote response.

Despite the regional nature of the increased aerosol burden, widespread surface cooling is found across the whole globe when comparing $\mathrm{HighSO}_{2}$ to $\mathrm{LowSO}_{2}$, with the exception of a few areas over Asia and the northwestern Pacific (Fig. 8a). Most of the changes are statistically significant, with the strongest cooling located over large parts of Europe even though the region does not show any significant change in anthropogenic aerosols between the two scenarios. This underscores the important role of atmospheric circulation adjustments in spreading local perturbations via changes in heat transport (Ming and Ramaswamy 2009). The role of oceanic heat transport is deemed minor because of its slower response time than the time-scale of the analysis.

The spatial pattern of near-surface temperature differences between $\mathrm{HighSO}_{2}$ and $\mathrm{LowSO}_{2}$ (Fig. 8a) strongly resembles the changes in upper-level streamfunction (Fig. 7b) which is linked to diabatic forcing over Asia. Given this similarity, it is reasonable to expect that extratropical wave anomalies originating from Asia play an important role in generating the remote temperature changes by adiabatic redistribution of the extratropical temperature field via circulation adjustments. For example, the large upper tropospheric trough over Eurasia is associated with an extended area of anomalous low sea level pressure (Fig. 8b) in an equivalent barotropic structure. The latter advects cold polar air over the region, leading to anomalous
Fig. 8 Spatial patterns of the 2010-2023 global mean difference between $\mathrm{HighSO}_{2}$ and LowSO $\mathrm{S}_{2}$ during June-August (JJA) for a surface temperature $(\mathrm{K})$; b sea level pressure $(\mathrm{hPa}$; shades) and $850-\mathrm{hPa}$ winds (m $\mathrm{s}^{-1}$; arrows); and c precipitation $\left(\mathrm{mm} \mathrm{day}^{-1}\right.$; shades) with Low $\mathrm{SO}_{2}$ average values for the same time period (contours at 8 and $12 \mathrm{~mm} \mathrm{day}^{-1}$ ) to show the position of the ITCZ. Stippling indicates significance at the $90 \%$ level ( $\mathrm{p}>0.1)$ using a twosample Kolmogorov-Smirnov test (a)

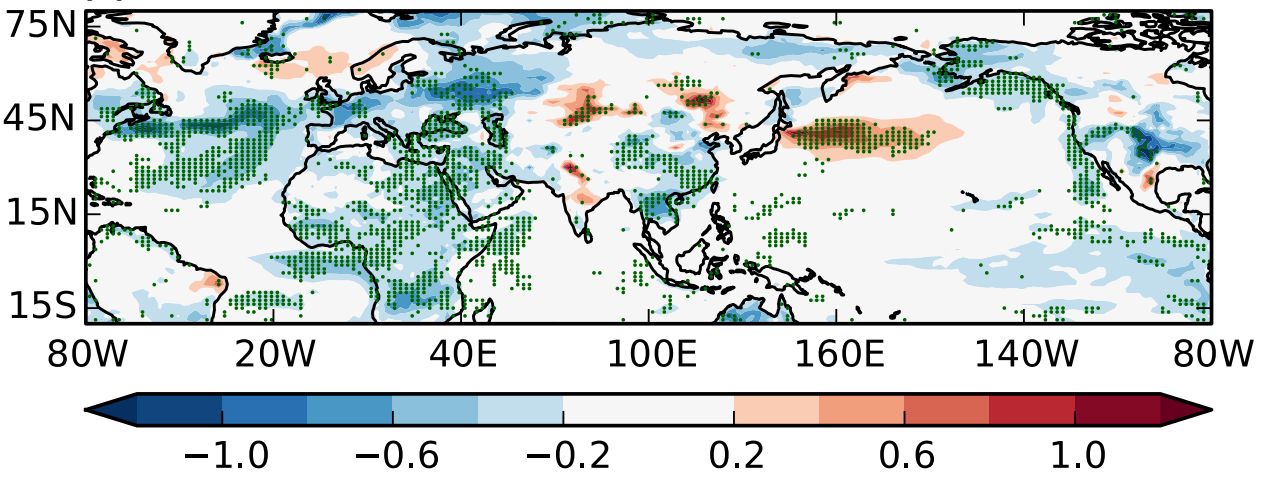

(b) $\longrightarrow 1.0 \mathrm{~m} \mathrm{~s}^{-1}$

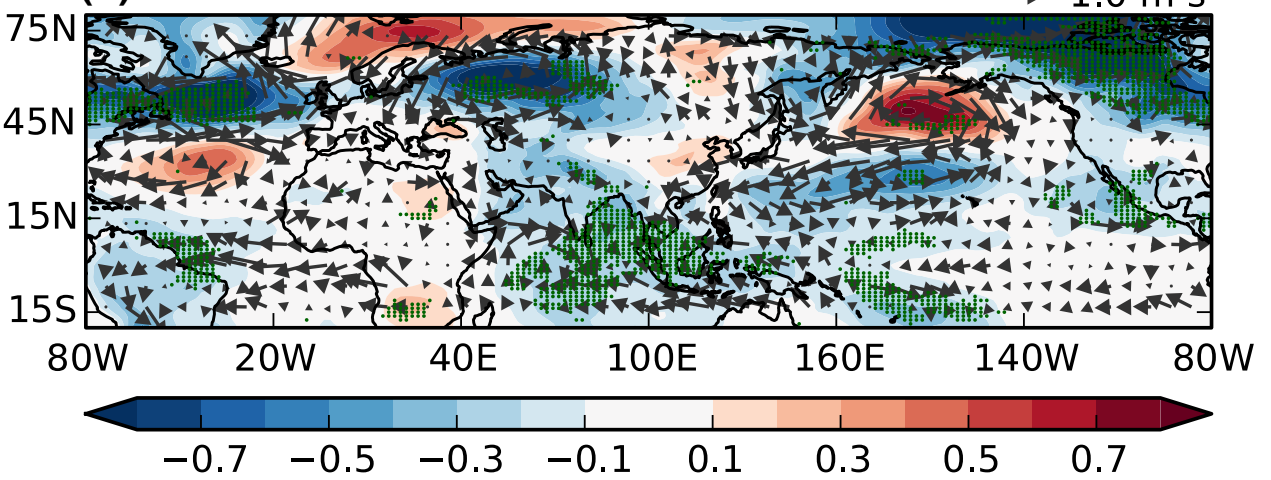

(c)

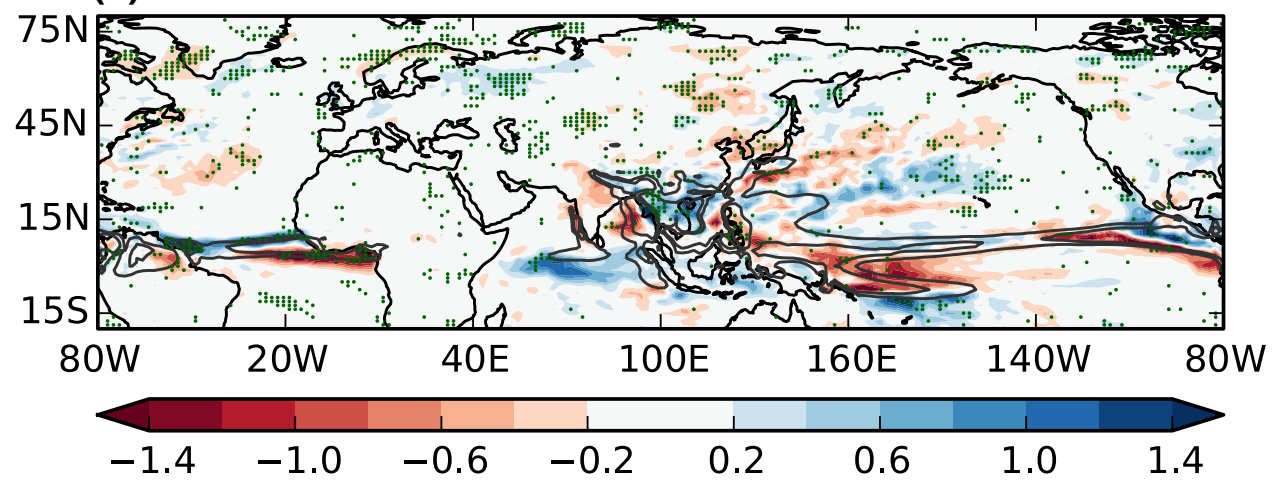


cooling in $\mathrm{HighSO}_{2}$ relative to $\mathrm{LowSO}_{2}$. For similar reasons, warm advection occurs over central Eurasia, leading to anomalous warming. Although focused on wintertime global anthropogenic aerosol forcing and thus not directly comparable to our study, Ming et al. (2011) and Lewinschal et al. (2012) also found aerosol-induced changes in tropical precipitation and diabatic heating to be very effective in generating a Rossby wave response across the extratropics, in turn leading to large remotely-forced temperature anomalies.

The temperature anomalies (Fig. 8a) over the equatorial and North Pacific are reminiscent of the pattern of the negative phase of the Pacific Decadal Oscillation (PDO). These changes are also accompanied by stronger easterly trade winds in $\mathrm{HighSO}_{2}$ compared to those in $\mathrm{LowSO}_{2}$ (Fig. 8b) across the equatorial Pacific, as expected in association with the westward shift of convection over the equatorial Indian Ocean (seen through precipitation differences between $\mathrm{HighSO}_{2}$ and $\mathrm{LowSO}_{2}$ in Fig. 8c). One feature of the SST pattern is the large anomalous North Pacific warming, extending from the eastern coast of Japan. Coupled ocean-atmosphere interactions contribute to generating this anomaly: an anomalous anticyclone/cyclone dipole appears over the northern/southern flank of the climatological western Pacific high, and the resulting anomalous easterly flow weakens the climatological southwesterly wind over the western side of the basin. This leads to lower cloud fraction and liquid water path, and increased downward shortwave radiation at the surface which acts to increase SST. Despite the weaker winds, evaporation increases in response to warmer SST in $\mathrm{HighSO}_{2}$ compared to those in $\mathrm{LowSO}_{2}$, providing a controlling mechanism. These results expand upon and are supported by Allen et al. (2014), who suggested the existence of a link between global anthropogenic aerosols and PDO trends, and by Boo et al. (2015), who found an important contribution of Chinese emissions in driving Pacific decadal SST variability. Additionally, Smith et al. (2016) found a similar pressure pattern induced by aerosols, particularly in the Aleutian low region, and linked it to propagation of a wave train across the Pacific and a planetary wave response.

The precipitation differences between $\mathrm{HighSO}_{2}$ and LowSO $\mathrm{S}_{2}$ (Fig. 8c) outside Asia and the Maritime Continent show a northwestward shift in the Intertropical Convergence Zone (ITCZ) across the Atlantic and the eastern Pacific. Note that, while not certainly free from known biases, the model captures the main features of the climatological ITCZ (Waliser and Somerville 1994). Such a shift can be understood by looking at the aerosol-induced pattern of zonal cells along the equator discussed previously (Fig. 7a), and specifically the area of widespread subsidence over the Gulf of Guinea associated with the anomalous upper-level anticyclone (Fig. 7b) induced by the
Gill-type response to the convective heating anomaly over the central equatorial Indian Ocean (Lu 2009). At lower levels, the climatological North African low pressure centre strengthens and the Arabian Peninsula low pressure centre weakens in $\mathrm{HighSO}_{2}$ compared to those in $\mathrm{LowSO}_{2}$ (Fig. 8b). The overall effect appears to be a northwestward shift of the region of maximum ascent away from the monsoon region. Dong et al. (2014) and Grandey et al. (2016) similarly find that Asian aerosols can impact on the West African monsoon through alterations to zonal cells, leading to reduced precipitation in the Sahel region.

We find similarities with observations showing strengthening and a westward shift of the Pacific Walker circulation (Ma and Zhou 2016) which would result in a repositioning of major convective precipitation regions. Although set in a different time context, the plausibility of the response seen in the present study is supported by Ma and Zhou (2016), with modelling results showing enhanced Indian Ocean, Indonesian, and Central American precipitation, and supressed precipitation over the central Pacific in relation to Pacific Walker circulation changes.

\section{Discussion and Conclusions}

Using HadGEM2-ES, we have investigated the near-term response of the Asian summer monsoon system to different future aerosol emission scenarios. The scenarios use differing anthropogenic aerosol emissions chosen to span a potential range of future global $\mathrm{SO}_{2}$ emissions but share RCP2. $6 \mathrm{CO}_{2}$ forcing: a selection designed to explore the impacts of uncertainty in aerosol emissions for a common GHG forcing pathway. Sulfur dioxide from Chinese sources is by far the largest contributor to the global emissions difference, inducing substantial climate impacts during summer, both locally and remotely, via sulfate aerosoldriven changes in the East Asian monsoon and subsequent redistribution of convective precipitation over Southeast Asia. We also note that sulfate is the dominant anthropogenic aerosol species for China (Lu et al. 2011) making its impacts an important topic of study.

Increased East Asian sulfate aerosols are found to significantly impact regional climate: surface cooling over northern China hinders the northward progression of the monsoon, causing it to stagnate over Indochina. This stagnation is linked to surface cooling via anomalous high pressure and circulation changes, similar to Dong et al. (2016). Both the aerosol direct and indirect effects contribute to generating these anomalies. The resulting precipitation dipole somewhat resembles the recently observed SFND pattern. This is further linked, via anomalous atmospheric circulation patterns, to a weakening and drying of the South Asian monsoon, which supports and extends previous findings on 
the primary role of aerosols in driving its historical multidecadal drying. Such changes to the Asian monsoon can have serious impacts on agriculture, health, water, economies, and ecosystems of the region, due to their strong reliance on the (spatial and temporal) regularity of monsoon rainfall.

Anomalous monsoon diabatic heating induces largescale circulation changes in the upper troposphere which propagate across the northern hemisphere via Rossby waves. Due to this wave pattern we find that aerosol uncertainty in East Asia leads to impacts on European climate, particularly in terms of surface temperature. We also find significant changes over other remote areas, such as Africa and the North Pacific, showing that regional aerosol uncertainty can result in hemispheric-scale climate impacts. A link between Asian and African climate has been previously suggested (Chung and Ramanathan 2006; Lu 2009; Dong et al. 2014). Notably, we find changes to the global zonal circulation across tropical regions which provides a connection to other monsoon systems. This is induced by shifts in convective regions, for example over the Indian Ocean and western Pacific, which have previously been linked to Asian aerosols (Chung et al. 2002). Further, this zonal circulation, specifically the Pacific Walker cell, could potentially impact the El Niño Southern Oscillation with further implications for global climate.

The modelled Pacific SST differences between $\mathrm{HighSO}_{2}$ and $\mathrm{LowSO}_{2}$ bear striking resemblance to the characteristic pattern of the negative phase of the PDO, which has been associated with the recent hiatus of global warming (Kosaka and Xie 2013). This adds support to other studies which have linked anthropogenic aerosols to PDO phases (e.g. Allen et al. 2014; Boo et al. 2015). This raises the possibility that increased East Asian aerosols during the recent decades may have contributed to slowing down the rate of increase of global mean surface temperature, as recently suggested (Smith et al. 2016). This would imply that future reduction of anthropogenic aerosol emissions, particularly from China, would promote a positive PDO and lead to a further increase in global mean surface temperature trends over the coming years.

The aerosol impact found here and the potential to induce remote anomalies is effective because of perturbation to the extensive Asian summer monsoon system. However, it is worth mentioning that large-scale anomalies appear year-round. It is not unreasonable to expect that such aerosol-driven year-round anomalies could plausibly link to wintertime downstream impacts on features such as the North Atlantic Oscillation, for example through El Niño-North Atlantic Oscillation interactions (Dunstone et al. 2016). Investigating such year-round impacts is beyond the scope of the present study but will be the topic of a forthcoming analysis. Although the winter season has been mostly overlooked so far, existing studies have shown that Asian aerosols may affect wintertime climate over remote regions (e.g. enhanced Austrialian precipitation; Grandey et al. 2016) as well as having the potential to induce hemisphere-wide anomalies (Ming et al. 2011; Lewinschal et al. 2012).

We acknowledge some limitations of this study. While the scenarios benefit from being based on peer reviewed bottom up scenarios of possible emissions, they are not designed to investigate the impact of East Asian sulfate aerosol in isolation. Thus, impacts from other local species could occur although, as discussed, differences between the two scenarios in this respect are small. There are also, albeit small, differences in aerosol amounts in other parts of the globe which could affect results. Secondly, the experiments only consist of three ensemble members; this is consistent with experiments used in other studies but the availability of more members would help to more robustly isolate the forced response from the background of internal variability. Finally, we acknowledge that the simulated response might be affected by model biases in reproducing certain characteristics of the Asian monsoon (Wilcox et al. 2015a).

In summary, this study provides a new perspective on identifying the plausible impact of near-future aerosols. Further, atmospheric circulation adjustments are shown to play a vital role in extending impacts to hemispheric scales, suggesting that addressing circulation changes is key to reducing uncertainties in future regional and global climate variability. Using scenarios which represent a range of sulfate aerosol pathways within a widely studied future $\mathrm{CO}_{2}$ forcing trajectory, we show that aerosol emissions represent an important source of uncertainty in near-term projection of regional climate, building upon the work of previous studies which look at past aerosols and idealised future aerosols. Additionally, this uncertainty could be important in the context of GHG-induced climate change, as aerosols may exacerbate or counteract GHG impacts. Consequently, we urge for a careful examination of the uncertainties associated with aerosol pathways in future climate assessments and for diligent consideration of aerosol emissions in future experimental design, for example, within the upcoming Coupled Model Intercomparison Project Phase 6.

Acknowledgements The authors would like to thank two anonymous reviewers for their insightful comments which helped to improve the manuscript. This work was supported by the Natural Environment Research Council (NERC) through the Edinburgh Earth and Environment Doctoral Training Partnership (E3 DTP). This work and Massimo A. Bollasina were also supported by the UK-China Research and Innovation Partnership Fund through the Met Office Climate Science for Service Partnership (CSSP) China as part of the Newton Fund. We acknowledge CEDA for data access via JASMIN to the HadGEM2-ES preindustrial control experiment data. 
Open Access This article is distributed under the terms of the Creative Commons Attribution 4.0 International License (http:// creativecommons.org/licenses/by/4.0/), which permits unrestricted use, distribution, and reproduction in any medium, provided you give appropriate credit to the original author(s) and the source, provide a link to the Creative Commons license, and indicate if changes were made.

\section{References}

Albrecht BA (1989) Aerosols, cloud microphysics, and fractional cloudiness. Science 245(4923):1227-1230. doi:10.1126/ science. 245.4923 .1227

Allen MR, Frame DJ, Huntingford C, Jones CD, Lowe JA, Meinshausen M, Meinshausen N (2009) Warming caused by cumulative carbon emissions towards the trillionth tonne. Nature 458:1163-1166. doi:10.1038/nature08019

Allen RJ, Norris JR, Kovilakam M (2014) Influence of anthropogenic aerosols and the Pacific Decadal Oscillation on tropical belt width. Nature Geosci 7(4):270-274. doi:10.1038/ngeo2091

Bellouin N, Rae J, Jones A, Johnson C, Haywood J, Boucher O (2011) Aerosol forcing in the climate model intercomparison project (CMIP5) simulations by HadGEM2-ES and the role of ammonium nitrate. J Geophys Res 116:D20206. doi:10.1029/201 1JD016074

Bellucci A, Haarsma R, Bellouin N, Booth B, Cagnazzo C, van den Hurk B, Keenlyside N, Koenigk T, Massonnet F, Materia S, Weiss M (2015) Advancements in decadal climate predictability: the role of nonoceanic drivers. Rev Geophys 53(2):165-202. doi: 10.1002/2014RG000473

Bollasina MA, Ming Y, Ramaswamy V (2011) Anthropogenic aerosols and the weakening of the south asian summer monsoon. Science 334(6055):502-505. doi:10.1126/science.1204994

Bollasina MA, Ming Y, Ramaswamy V, Schwarzkopf MD, Naik V (2014) Contribution of local and remote anthropogenic aerosols to the twentieth century weakening of the South Asian Monsoon. Geophys Res Lett 41(2):680-687. doi:10.1002/2013GL058183

Boo KO, Booth BBB, Byun YH, Lee J, Cho C, Shim S, Kim KT (2015) Influence of aerosols in multidecadal SST variability simulations over the North Pacific. J Geophys Res Atmos 120(2):517-531. doi:10.1002/2014JD021933

Boucher O, Randall D, Artaxo P, Bretherton C, Feingold G, Forster P, Kerminen VM, Kondo Y, Liao H, Lohmann U, Rasch P, Satheesh S, Sherwood S, Stevens B, Zhang X (2013) Clouds and aerosols. In: Climate change 2013: the physical science basis. Contribution of Working Group I to the Fifth Assessment Report of the Intergovernmental Panel on Climate Change. Cambridge University Press, Cambridge, United Kingdom and New York, NY, USA, pp 571-658, doi:10.1017/CBO9781107415324\$4016

Chalmers N, Highwood EJ, Hawkins E, Sutton R, Wilcox LJ (2012) Aerosol contribution to the rapid warming of near-term climate under RCP 2.6. Geophys Res Lett 39(18):L18709. doi:10.1029/ 2012GL052848

Chang CP, Zhang Y, Li T (2000) Interannual and interdecadal variations of the East Asian summer monsoon and tropical pacific SSTs. Part I: roles of the subtropical ridge. J Clim 13(24):4310 4325. doi:10.1175/15200442(2000)013<4310:IAIVOT > 2.0 . $\mathrm{CO} ; 2$

Charlson RJ, Schwartz SE, Hales JM, Cess RD, Coakley JA, Hansen JE, Hofmann DJ (1992) Climate forcing by anthropogenic aerosols. Science 255(5043):423-430. doi:10.1126/ science.255.5043.423
Chung CE, Ramanathan V (2006) Weakening of North Indian SST gradients and the monsoon rainfall in India and the Sahel. J Clim 19(10):2036-2045. doi:10.1175/JCLI3820.1

Chung C, Ramanathan V, Kiehl J (2002) Effects of the South Asian absorbing haze on the northeast monsoon and surface-air heat exchange. J Clim 15:2462-2476. doi:10.1175/1520-0442(2002)015>2.0.CO;2

Clarke L, Jiang K, Akimoto K, Babiker M, Blanford G, Fisher-Vanden K, Hourcade JC, Krey V, Kriegler E, Löschel A, McCollum D, Paltsev S, Rose S, Shukla P, Tavoni M, van der Zwaan B, van Vuuren D (2014) Assessing transformation pathways. In: Climate change 2014: mitigation of climate change. Contribution of Working Group III to the Fifth Assessment Report of the Intergovernmental Panel on Climate Change. Cambridge University Press, Cambridge, pp 413-510

Collins WJ, Bellouin N, Doutriaux-Boucher M, Gedney N, Halloran P, Hinton T, Hughes J, Jones CD, Joshi M, Liddicoat S, Martin G, O'Connor F, Rae J, Senior C, Sitch S, Totterdell I, Wiltshire A, Woodward S (2011) Development and evaluation of an earthsystem model HadGEM2. Geosci Model Dev 4(4):1051-1075. doi:10.5194/gmd-4-1051-2011

Cowan T, Cai W (2011) The impact of Asian and non-Asian anthropogenic aerosols on 20th century Asian summer monsoon. Geophys Res Lett 38(11):L11703. doi:10.1029/2011GL047268

Ding Q, Wang B (2005) Circumglobal teleconnection in the northern hemisphere summer. J Clim 18(17):3483-3505. doi:10.1175/ JCLI3473.1

Dong B, Sutton RT, Highwood E, Wilcox L (2014) The impacts of European and Asian anthropogenic sulfur dioxide emissions on Sahel rainfall. J Clim 27(18):7000-7017. doi:10.1175/ JCLI-D-13-00769.1

Dong B, Sutton RT, Highwood EJ, Wilcox LJ (2016) Preferred response of the East Asian summer monsoon to local and nonlocal anthropogenic sulphur dioxide emissions. Clim Dyn 46(5):1733-1751. DOI:10.1007/s00382-015-2671-5

Dunstone N, Smith D, Scaife A, Hermanson L, Eade R, Robinson N, Andrews M, Knight J (2016) Skilful predictions of the winter North Atlantic oscillation one year ahead. Nature Geosci 9(11):809-814. doi:10.1038/ngeo2824

Ganguly D, Rasch PJ, Wang H, Yoon JH (2012) Climate response of the South Asian monsoon system to anthropogenic aerosols. J Geophys Res Atmos 117(D13):D13209. doi:10.1029/201 2JD017508

Gillett NP, Salzen KV (2013) The role of reduced aerosol precursor emissions in driving near-term warming. Environ Res Lett 8(3):034008. doi:10.1088/17489326/8/3/034008

Gong DY, Ho CH (2002) Shift in the summer rainfall over the Yangtze River valley in the late 1970s. Geophys Res Lett 29(10):78-178-78-1-74. doi:10.1029/2001GL014523

Grandey BS, Cheng H, Wang C (2016) Transient climate impacts for scenarios of aerosol emissions from Asia: A story of coal versus gas. J Clim 29(8):2849-2867. doi:10.1175/JCLI-D-15-0555.1

Guo L, Highwood EJ, Shaffrey LC, Turner AG (2013) The effect of regional changes in anthropogenic aerosols on rainfall of the East Asian summer monsoon. Atmos Chem Phys 13(3):1521-1534. doi:10.5194/acp-13-1521-2013

Guo L, Turner AG, Highwood EJ (2015) Impacts of 20th century aerosol emissions on the South Asian monsoon in the CMIP5 models. Atmos Chem Phys 15(11):6367-6378. doi:10.5194/ acp-15-6367-2015

Hansen J, Sato M, Ruedy R (1997) Radiative forcing and climate response. J Geophys Res Atmos 102(D6):6831-6864. doi:10.1029/96JD03436

Haywood J, Boucher O (2000) Estimates of the direct and indirect radiative forcing due to tropospheric aerosols: a review. Rev Geophys 38(4):513-543. doi:10.1029/1999RG000078 
Jin F, Hoskins BJ (1995) The direct response to tropical heating in a Baroclinic atmosphere. J Atmos Sci 52(3):307-319. doi:10.1175 /15200469(1995)052<0307:TDRTTH>2.0.CO;2

Jones CD, Hughes JK, Bellouin N, Hardiman SC, Jones GS, Knight J, Liddicoat S, O'Connor FM, Andres RJ, Bell C, Boo KO, Bozzo A, Butchart N, Cadule P, Corbin KD, Doutriaux-Boucher M, Friedlingstein P, Gornall J, Gray L, Halloran PR, Hurtt G, Ingram WJ, Lamarque JF, Law RM, Meinshausen M, Osprey S, Palin EJ, Parsons Chini L, Raddatz T, Sanderson MG, Sellar AA, Schurer A, Valdes P, Wood N, Woodward S, Yoshioka M, Zerroukat M (2011) The HadGEM2-ES implementation of CMIP5 centennial simulations. Geosci Model Dev 4(3):543-570. doi:10.5194/gmd-4-543-2011

Kirtman B, Power SB, Adedoyin JA, Boer GJ, Bojariu R, Camilloni I, Doblas-Reyes FJ, Fiore AM, Kimoto M, Meehl GA, Prather M, Sarr A, Schär C, Sutton R, van Oldenborgh, GJ Vecchi G, Wang HJ (2013) Near-term climate change: projections and predictability. In: Climate change 2013: the physical science basis. Contribution of Working Group I to the Fifth Assessment Report of the Intergovernmental Panel on climate change. Cambridge University Press, Cambridge, pp 953-1028. doi:10.1017/ CBO9781107415324\$4023

Kosaka Y, Xie S-P (2013) Recent global-warming hiatus tied to equatorial Pacific surface cooling. Nature 501(7467):403-407. doi:10.1038/nature12534

Krey V, Masera O, Blanford G, Bruckner T, Cooke R, Fisher-Vanden K, Haberl H, Hertwich E, Kriegler E, Mueller D, Paltsev S, Price L, Schlmer S, Ürge-Vorsatz D, van Vuuren D, Zwickel T (2014) Annex II: metrics \& methodology. In: Climate Change 2014: mitigation of climate change. Contribution of Working Group III to the Fifth Assessment Report of the Intergovernmental Panel on Climate Change. Cambridge University Press, Cambridge

Lamarque JF, Kyle PP, Meinshausen M, Riahi K, Smith SJ, van Vuuren DP, Conley AJ, Vitt F (2011) Global and regional evolution of short-lived radiatively-active gases and aerosols in the representative concentration pathways. Clim Change 109(1):191-212. doi:10.1007/s10584-011-0155-0

Lau WKM, Kim KM (2010) Fingerprinting the impacts of aerosols on long-term trends of the Indian summer monsoon regional rainfall. Geophys Res Lett 37(16):L16705. doi:10.1029/201 0GL043255

Lee SY, Shin HJ, Wang C (2013) Nonlinear effects of coexisting surface and atmospheric forcing of anthropogenic absorbing aerosols: impact on the South Asian monsoon onset. J Clim 26(15):5594-5607. doi:10.1175/JCLI-D-12-00741.1

Lewinschal A, Ekman AML, Körnich H (2012) The role of precipitation in aerosol induced changes in northern hemisphere wintertime stationary waves. Clim Dyn 41(3):647-661. doi:10.1007/ s00382-012-1622-7

Lin H (2009) Global extratropical response to diabatic heating variability of the Asian summer monsoon. J Atmos Sci 66(9):26972713. doi:10.1175/2009JAS3008.1

Lu J (2009) The dynamics of the Indian Ocean sea surface temperature forcing of Sahel drought. Clim Dyn 33(4):445-460. doi:10.1007/s00382-009-0596-6

Lu Z, Zhang Q, Streets DG (2011) Sulfur dioxide and primary carbonaceous aerosol emissions in China and India, 19962010. Atmos Chem Phys 11(18):9839-9864. doi:10.5194/acp-11-9839-2011

Ma S, Zhou T (2016) Robust strengthening and westward shift of the tropical pacific walker circulation during 19792012: a comparison of 7 Sets of reanalysis data and 26 CMIP5 models. J Clim 29(9):3097-3118. doi:10.1175/JCLI-D-15-0398.1

Mahmood R, Li S (2014) Remote influence of South Asian black carbon aerosol on East Asian summer climate. Int $\mathrm{J}$ Climatol 34(1):36-48. doi:10.1002/joc.3664
Matthews HD, Gillett NP, Stott PA, Zickfeld K (2009) The proportionality of global warming to cumulative carbon emissions. Nature 459:829-832. doi:10.1038/nature08047

Meinshausen M, Meinshausen N, Hare W, Raper SCB, Frieler K, Knutti R, Frame DJ, Allen MR (2009) Greenhouse-gas emission targets for limiting global warming to 2 c. Nature $458: 1158$ 1162. doi:10.1038/nature08017

Menon S, Hansen J, Nazarenko L, Luo Y (2002) Climate effects of black carbon aerosols in China and India. Science 297(5590):2250-2253. doi:10.1126/science.1075159

Ming Y, Ramaswamy V (2009) Nonlinear climate and hydrological responses to aerosol effects. J Clim 22(6):1329-1339. doi:10.11 75/2008JCLI2362.1

Ming Y, Ramaswamy V (2011) A model investigation of aerosolinduced changes in tropical circulation. J Clim 24(19):51255133. doi:10.1175/2011JCLI4108.1

Ming Y, Ramaswamy V, Chen G (2011) A model investigation of aerosol-induced changes in boreal winter extratropical circulation. J Clim 24:6077-6091. doi:10.1175/2011JCLI4111.1

Myhre G, Shindell D, Breon FM, Collins W, Fuglestvedt J, Huang J, Koch D, Lamarque JF, Lee D, Mendoza B, Nakajima T, Robock A, Stephens G, Takemura T, Zhang H (2013) Anthropogenic and natural radiative forcing. In: Climate change 2013: the physical science basis. Contribution of Working Group I to the Fifth Assessment Report of the Intergovernmental Panel on Climate Change. Cambridge University Press, Cambridge, United Kingdom and New York, NY, USA, pp 659-740, doi:10.1017/ CBO9781107415324\$4018

Ramanathan V, Crutzen PJ, Kiehl JT, Rosenfeld D (2001) Aerosols, climate, and the hydrological cycle. Science 294(5549):21192124. doi:10.1126/science.1064034

Riahi K, Kriegler E, Johnson N, Bertram C, den Elzen M, Eom J, Schaeffer M, Edmonds J, Isaac M, Krey V, Longden T, Luderer G, Mjean A, McCollum DL, Mima S, Turton H, van Vuuren DP, Wada K, Bosetti V, Capros P, Criqui P, Hamdi-Cherif M, Kainuma M, Edenhofer O (2015) Locked into Copenhagen pledges Implications of short-term emission targets for the cost and feasibility of long-term climate goals. Technol Forecast Soc Change 90(Part A):8-23. doi:10.1016/j.techfore.2013.09.016

Rotstayn L, Plymin E, Collier M, Boucher O, Dufresne J, Luo J, von Salzen K, Jeffrey S, Foujols M, Ming Y, Horowitz L (2014) Declining aerosols in CMIP5 projections: effects on atmospheric temperature structure and midlatitude jets. J Clim 27:6960-6977. doi:10.1175/JCLI-D-14-00258.1

Sardeshmukh PD, Hoskins BJ (1988) The generation of global rotational flow by steady idealized tropical divergence. J Atmos Sci 45(7):1228-1251. doi:10.1175/1520-0469(1988)045<1228:TGO GRF $>2.0 . \mathrm{CO} ; 2$

Shindell DT, Lamarque J-F, Schulz M, Flanner M, Jiao C, Chin M, Young PJ, Lee YH, Rotstayn L, Mahowald N, Milly G, Faluvegi G, Balkanski Y, Collins WJ, Conley AJ, Dalsoren S, Easter R, Ghan S, Horowitz L, Liu X, Myhre G, Nagashima T, Naik V, Rumbold ST, Skeie R, Sudo K, Szopa S, Takemura T, Voulgarakis A, Yoon J-H, Lo F (2013) Radiative forcing in the ACCMIP historical and future climate simulations. Atmos Chem Phys 13:2939-2974. doi:10.5194/acp-13-2939-2013

Smith DM, Booth BBB, Dunstone NJ, Eade R, Hermanson L, Jones GS, Scaife AA, Sheen KL, Thompson V (2016) Role of volcanic and anthropogenic aerosols in the recent global surface warming slowdown. Nature Clim Change 6:936-940. doi:10.1038/ nclimate 3058

Song F, Zhou T, Qian Y (2014) Responses of East Asian summer monsoon to natural and anthropogenic forcings in the 17 latest CMIP5 models. Geophys Res Lett 41(2):596-603. doi:10.1002/ 2013GL058705 
Sperber KR, Annamalai H, Kang IS, Kitoh A, Moise A, Turner A, Wang B, Zhou T (2013) The Asian summer monsoon: an intercomparison of CMIP5 vs. CMIP3 simulations of the late 20th century. Clim Dyn 41(9):2711-2744. doi:10.1007/ s00382-0121607-6

Takaya K, Nakamura H (2001) A formulation of a phase-independent wave-activity flux for stationary and migratory quasigeostrophic eddies on a zonally varying basic flow. J Atmos Sci 58(6):608627. doi:10.1175/15200469(2001)058<0608:AFOAPI $>2.0$ . $\mathrm{CO} ; 2$

Teng H, Washington WM, Branstator G, Meehl GA, Lamarque JF (2012) Potential impacts of Asian carbon aerosols on future US warming. Geophys Res Lett 39(11):L11703. doi:10.1029/201 2GL051723

Trenberth KE, Stepaniak DP, Caron JM (2000) The global monsoon as Seen through the divergent atmospheric circulation. J Clim 13(22):3969-3993. doi:10.1175/1520-0442(2000)013<3969:TGMAST>2.0.CO;2

Twomey S (1977) The Influence of pollution on the shortwave albedo of clouds. J Atmos Sci 34(7):1149-1152. doi:10.1175/1520-0469(1977)034<1149:TIOPOT>2.0.CO;2

van Vuuren DP, Edmonds J, Kainuma M, Riahi K, Thomson A, Hibbard K, Hurtt GC, Kram T, Krey V, Lamarque JF, Masui T, Meinshausen M, Nakicenovic N, Smith SJ, Rose SK (2011)
The representative concentration pathways: an overview. Clim Change 109(1):5-31. doi:10.1007/s10584-011-0148-Z

Waliser D, Somerville R (1994) Preferred latitudes of the intertropical convergence zone. J Atmos Sci 51:1619-1639. doi:10.1175/1520-0469(1994)051>2.0.CO;2

Wang TJ, Zhuang BL, Li S, Liu J, Xie M, Yin CQ, Zhang Y, Yuan C, Zhu JL, Ji LQ, Han Y (2015) The interactions between anthropogenic aerosols and the East Asian summer monsoon using RegCCMS. J Geophys Res Atmos 120(11):5602-5621. doi:10.1002/2 014JD022877

Westervelt DM, Horowitz LW, Naik V, Golaz JC, Mauzerall DL (2015) Radiative forcing and climate response to projected 21st century aerosol decreases. Atmos Chem Phys 15(22):1268112703. doi:10.5194/acp-15-12681-2015

Wilcox LJ, Dong B, Sutton RT, Highwood EJ (2015a) The 2014 hot, dry summer in Northeast Asia. Bull Am Meteorol Soc 96(12):S105-S110. doi:10.1175/BAMS-D-15-00123.1

Xie SP, Lu B, Xiang B (2013) Similar spatial patterns of climate responses to aerosol and greenhouse gas changes. Nature Geosci 6(10):828-832. doi:10.1038/ngeo1931

Xu Q (2001) Abrupt change of the mid-summer climate in central east China by the influence of atmospheric pollution. Atmos Environ 35(30):5029-5040. doi:10.1016/S1352-2310(01)00315-6 